ISSN: 2148-2586

BUSINESS \& MANAGEMENT STUDIES:

AN INTERNATIONAL JOURNAL

Vol.:7 Issue:5 Year:2019, pp. 2489-2524

Citation: Berber, Ş. \& Can, E. (2019), Erken Uluslararasılaşmada A ̆̆ İlişkilerinin Rolü Üzerine

Bir Örnek Olay Çalışması: Turkuaz Yatak Örneği, BMIJ, (2019), 7(5): 2489-2524 doi: http://dx.doi.org/10.15295/bmij.v7i5.1331

\title{
ERKEN ULUSLARARASILAŞMADA AĞ İLIŞKILERININ ROLÜ ÜZERINE BİR ÖRNEK OLAY ÇALIŞMASI: TURKUAZ YATAK ÖRNEĞİ
}

Şayan BERBER ${ }^{1}$

Esin $\mathrm{CAN}^{2}$

$\ddot{O} Z$
Received Date (Başvuru Tarihi): 06/11/2019

Accepted Date (Kabul Tarihi): 19/12/2019

Published Date (Yayın Tarihi): 25/12/2019

Kuruluşlarıyla beraber veya kuruluşlarını müteakip kısa süreler içerisinde uluslararasılaşan işletmeler, dünya çapında sayıca artmaktadır. Bu çalışma, yabancı pazarlarda önemli gelir akışları yaratabilen bu işletmelerin, başarılarının temel dinamiklerinden biri olarak görülen, "ă̆ ilişkilerine” odaklanmaktadır. Araştırmada, ăg ilişkilerinin işletmelerin erken uluslararasılaşmasındaki rolünün, Türkiye özelinde bir örnek yardımıyla ortaya konulması amaçlanmaktadır. Bu bağlamda, Küçük ve Orta Ölçekli Işsletmeleri Geliştirme ve Destekleme İdaresi Başkanlı̆̆ı (KOSBEB) tarafindan düzenlenen, 4. KOBİ ve Girişimcilik Ödülleri Yarışmasında, “Küresel Doğan Girişimci” kategorisi finalistlerinden Turkuaz Yatak'ın, ă̆ ilişkileri derinlemesine incelenerek, sosyal ve iş ă̆ ilişkileri temelinde sınıflandırılmakta ve erken uluslararasılaşmaya yönelik sağladıkları belirlenmeye çalışılmaktadır. Araştırmada, nitel araştırma yöntemlerinden, örnek olay deseni kullanılmaktadır. Yarı yapılandırllmış görüşme yöntemiyle elde edilen veriler, analiz edilerek bulgulara ulaşılmıştır. Bulgular; işletmenin erken uluslararasılaşmasında ă̆ ilişkilerinin oynadı̆̆ı önemli rolü ortaya koymaktadır. Işletmede tespit edilen ă̆ ilişkileri, yoğunlukla iş temellidir. Ancak erken uluslararasılaşmada, sosyal ă̆ ilişkilerinden de önemli yararlar să̆landı̆̆ anlaşılmıştır.

Anahtar Kelimeler: Küresel Doğan İşletmeler, Erken Uluslararasılaşma, Ă̆ İlişkileri

JEL Kodlart: M13, M16, M19

\section{A CASE STUDY ON THE ROLE OF NETWORKS IN EARLY INTERNATIONALIZATION: THE CASE OF TURKUAZ YATAK}

\section{ABSTRACT}

Businesses that are internationalized in a short period of time after their establishment are increasing in worldwide. This study focuses on "networks", which are considered as one of the fundamental dynamics of the success of these firms. The aim of the research is to reveal the role of networks in early internationalization with the help of an example in Turkey. In the research, single case study design is used. The case study firm, is the finalist in the Born Global Entrepreneur Of The Year Category, at the 4th SME and Entrepreneurship Awards, organized by Development and Support Administration of Small and Medium-Sized Enterprises (KOSGEB). The networks that were effective in early internationalization of the case firm was examined on the basis of social business networks and was determined what they provide for early internationalization. The data is obtained through the semi-structured interview method and analyzed. Results reveals the important role played by networks in early internationalization of the firm. It was observed that the firm's network, consisted mostly of business relationships. However, it was understood that social networks also provide significant benefits in early internationalization.

Keywords: Born Global Firms, Early Internationalization, Network

JEL Codes: M13, M16, M19

\footnotetext{
${ }^{1}$ Yıldız Teknik Üniversitesi, sayan.berber@gmail.com

${ }^{2}$ Prof. Dr., Yıldız Teknik Üniversitesi, eesincan@gmail.com
} 


\section{GíRiş}

Dünyanın tek pazar haline dönüşme eğilimi ve teknolojik gelişmelerin beraberinde getirdiği amansız rekabet koşulları, rekabet üstünlüğü sağlamaya çalışarak yaşamlarını sürdürmeyi amaçlayan günümüz işletmeleri için uluslararasılaşmayı bir zorunluluk haline getirmiştir. Bugün mikro düzeydeki işletmeler bile, kuruluşlarıyla birlikte ürün ve hizmetlerine uluslararası pazarlarda alan yaratabilmektedirler. $\mathrm{Bu}$ bağlamda işletmelerin uluslararasılaşmasını zaman alan bir öğrenme süreci ve aşamalı bir ilerlemeyle açıklayan geleneksel modeller, günümüz işletmelerinin uluslararasılaşma davranışlarını açıklamada yetersiz kalmıştır. Uluslararasılaşmada bu modellerce öne sürülen aşamalı ilerlemeye karşı çıkarak, işletmelerin tanımlı aşamaları yaşamadan uluslararası pazarlarda kısa bir süre içerisinde ve aktif olarak var olabileceklerini öngören küresel doğan işletme modeli ise, dünya çapında geniş ölçüde kabul görmektedir.

Küresel doğanlar tipik olarak sınırlı kaynaklarla karakterize edilen, yabancı pazar tecrübesinden yoksun, genç ve girişimci küçük işletmelerdir. Ancak sayılan tüm kısıtlarına rağmen kuruluşlarıyla beraber ürün ve hizmetlerinin önemli bir bölümünü yabancı pazarlarda satmak suretiyle, küresel piyasalarda rekabet avantajı elde edebilmektedirler. İşletmeler geleneksel modellerce vurgulanan gerekli pazar bilgisi ve deneyimsel bilgiyi, uzun zaman beklemek yerine ăg ilişkileri yoluyla kısa sürede elde edilebilmektedirler. Bu nedenle alan yazında erken uluslararasılaşmanın sağlanmasında, ağ ilişkilerinin kritik rol oynadığına işaret edilmektedir. $\mathrm{Bu}$ doğrultuda da küresel doğan işletme araştırmalarının öncülük ettiği uluslararası girişimcilik alanında, ağ yaklaşımı teorik olarak baskın bir bakış açısı olarak öne çıkmaktadır (Hoang \& Antoncic, 2003; O’Donnel, Gilmore, Cummins, \& Carson, 2001; SlotteKock \& Coviello, 2010).

İlk kez Johanson ve Mattsson (1988) tarafından ifade edilen "Uluslararasılaşmada A $\breve{g}$ Yaklaşımı”, işletmelerin uluslararasılaşmasını sahip oldukları ă̆ ilişkileri aracılığıyla açıklar. Yaklaşıma göre ilişskiler, bir nevi kaynak sağlayıcı olarak hizmet ederek, işletmelerin mevcut kaynak kısıtlarını aşmalarını kolaylaştırıp, uluslararasılaşmalarında etkin rol oynarlar. Alan yazında bu ilişkilerin yabancı pazarlarda fırsatların keşfinden başlayarak, pazar bilgisi edinilmesinde, pazara giriş yöntemi seçiminde ve işletmelerin sonraki gelişimleri için gerekli kaynak ve yeteneklerin sağlanmasında etkili olduğu ifade edilmektedir. Öte yandan ilişkiler aktör düzeyinde bir ayırıma tabi tutularak, sosyal ve iş ağı ilişkileri olmak üzere genellikle iki kategoriye ayrılmaktadır. Sosyal ve iş ağı ilişkilerinden hangisinin uluslararasılaşmada daha önemli olduğuyla ilgili ise alan yazında çeşitli tartışmalar süregelmektedir. 
Erken uluslararasılaşma ve doğrultusunda gelişen küresel doğan işletme fenomeni, dünya çapında çeşitli araştırmacıların yöneldiği ilgi çekici bir araştırma alanı haline gelmiş olsa da (Berber, Köle, Taşçı, \& Can, 2018), ülkemiz ekseninde konuyla ilgili yapılan araştırma sayısının oldukça sınırlı olduğu görülmektedir. Bu sınırlı sayıda araştırmadan da, ağ ilişkilerini doğrudan araştırma odağı alan çalışmalar nadirdir. Riddle ve Gillespie (2003), Türk hazır giyim sektöründe yeni kurulan firmaların ihracata yönelik bilgi edinmek için gayri resmi ve resmi sosyal ağ ilişkilerini nasıl kullandıklarını, nicel bir araştırma marifetiyle araştırmışlardır. 250 işletme ile gerçekleştirilen ve veri toplama aracı olarak anket yönteminin kullanıldığı araştırmanın örneklemi Türk işletmelerinden oluşsa da, kapsamı ağ ilişkilerinin ihracata yönelik bilgi edinimindeki rolü ile sınırlıdır. Baskici ve Ercil (2018), yine nicel bir araştırma kurgusuyla, Türkiye'deki işletmelerin uluslararasılaşmalarında kullandıkları ağ oluşturma mekanizmalarını ortaya çıkarmayı hedeflemişlerdir. Ankara ilinde çeşitli sektörlerde faaliyet gösteren 19'u küresel doğan olmak üzere, toplam 90 KOBİ ile gerçekleştirilen araştırmanın bulguları; işletmelerin ilk ihracat faaliyetlerinde temel olarak 3 tür ağ oluşturma mekanizmasından yararlandıklarını ortaya koymuştur. Buna göre, işletmelerin çoğunluğu $(\% 52,2)$ aktif bir şekilde ağ oluşturma faaliyetinde bulunmuş, diğger bir deyişle ilk ihracatlarında stratejik olarak kendileri tarafından oluşturdukları ağları kullanmışlardır. Bunun yanında sırasıyla mevcut tanıdıkları ile olan sosyal ilişkilerinden $(\% 23,3)$ ve mevcut müşteriler/tedarikçiler ile olan iş ilişkilerinden $(\% 13,3)$ faydalandıkları ortaya çıkmıştır. Ancak araştırmada ortaya konan bu ağ ilişkilerinden, işletmelerin uluslararasılaşma yolunda elde ettikleri üzerinde durulmamıştır.

Literatürdeki belirtilen boşluktan yola çıkılarak organize edilen çalışmamızda, keşifsel bir araştırma tasarımı kullanılarak, Türkiye örnekleminde ağ ilişkilerinin erken uluslararasılaşmaya yönelik tüm sağladıklarının, küresel doğan bir işletme üzerinden ortaya konulması amaçlanmaktadır. Ayrıca araştırmadan elde edilen bulgular, çeşitli ülkeler nezdinde yürütülen araştırmaların bulguları ile kıyaslanarak, Türkiye özelinde benzerlik ve farklılık gösteren durumlar belirlenmeye çalışılmaktadır. Araştırmamızda ă̆ ilişskilerinin erken uluslararasılaşmaya yönelik olarak sağladıklarının keşfedilmesi amaçlandığından, belli bir olguyu derinlemesine inceleme imkânı sağlayan nitel araştırma yöntemine başvurulmuştur. Bu doğrultuda nitel araştırma yöntemlerinden "örnek olay” deseni, en uygun yöntem olarak seçilmiştir. Araştırma tek bir işletme üzerinden yürütülmüş olsa da, başarısı tescilli iyi bir uygulama örneği üzerinden konuya açıklık getirmeye çalışması nedeniyle, yerli alan yazın için değerli görülmektedir. 
Çalışmamız kapsamında öncelikle uluslararasılaşmada küresel doğan işletme modeli, öncesinde gelişen geleneksel modellerden farklılıkları bağlamında ele alınmaktadır. Ardından uluslararasılaşmada ağ yaklaşımına değinilmekte ve iş- sosyal ağ ilişkilerinin işletmelerin erken uluslararasılaşmasını açıklamadaki önemleri tartışılmaktadır. Sonraki bölümde araştırma metodolojisi anlatılmakta, takip eden bölümde ise KOSGEB 4. KOBİ ve Girişimcilik Ödülleri Küresel Doğan Girişimci Kategorisi finalisti Turkuaz Yatak'ın girişimcisi ile yüz yüze yapılan, yarı yapılandırılmış görüşme neticesinde elde edilen bulgular paylaşılmaktadır. Sonraki bölümde, araştırmadan elde edilen bulgular değerlendirilmekte ve nihayetinde sonuç ve öneriler bölümüyle çalışmamız sona ermektedir.

\section{ULUSLARARASILAŞMADA KÜRESEL DOĞAN İŞLETME MODELI}

Uluslararası işletmecilik, işletmelerin ulusal sınırların ötesindeki ticaret ve yatırım faaliyetlerini ifade eder (Çavuşgil, Knight, \& Riesenberger, 2012). İşletmelerin bu faaliyetlerine açıklık getirmek için kavramsallaştırılmış uluslararasılaşma modelleri, geleneksel modeller ve küresel doğan işletme modeli olmak üzere bünyesinde temelde iki model barındırır. Geleneksel modeller şemsiyesi altında ise Uppsala Modeli ve Yenilikle İlişkili Modeller incelenmektedir. Özünde her iki model de, yavaş ve aşamalı bir uluslararasılaşma öngörmesiyle benzeşmektedir.

Johanson ve Vahlne (1977) tarafından geliştirilen Uppsala Uluslararasılaşma Modeli, uluslararasılaşmanın bir dizi aşamadan meydana geldiğini göstermekte, bilgi ve kaynak eksikliği nedeniyle işletmelerin uluslararasılaşma süreçlerinde yakın ve kültürel açıdan kendilerine benzer pazarları hedefleyerek, bu pazarlarda yeterli bilgi ve deneyim edinene kadar pazara ilave kaynak tahsisinde bulunmayacaklarını öngörmektedir (Çavuşgil, Knight, \& Üner, 2011). Zaman içerisinde ise işletmeler, giderek yabancı pazarlardaki sermaye taahhüdlerini artırırlar (Johanson \& Wiedersheim-Paul, 1975). Bu türden aşamalı bir öğrenme ve nihayetinde uluslararası genişleme zaman alacağı için, Uppsala Modeli'ne göre uluslararasılaşma yavaş gerçekleşen bir süreçtir. Uygulama ve teorik ilerlemelerle sağlanan değişiklikler doğrultusunda model, Johanson ve Vahlne tarafından 2009 yılında revize edilmiş ve ağ perspektifi dâhil edilerek geliştirilmiştir. Revize model, işletmelerin çeşitli ilişkilerle birbirine bağlı olduğu ve çeşitli aktörleri içeren bir iş ağına gömüldüğünü kabul ederek, uluslararasılaşmayı işletmelerin ağdaki konumlarını güçlendirmek ya da korumak amacıyla gerçekleştirdikleri eylemlerinin sonucu olarak görmektedir (Johanson \& Vahlne, 2009). 
Yenilikle İlişkili Modeller ise uluslararasılaşmanın başlangıcını, işletme içinde gerçekleşen bir dizi yönetim yeniliği ile ilişkilendirirler (Knight \& Çavuşgil, 1996). Yenilikle ilişkili modellerin temel olarak Bilkey ve Tesar (1977), Çavuşgil (1980), Reid (1981) ve Czinkota (1982)'nın çalışmalarından oluştuğu kabul edilir. Modeller kendi içlerinde uluslararasılaşmanın başlangıç mekanizmaları ve tanımladıkları basamak sayısı olarak farklılaşmakla beraber, bu farklılıklar gerçek bir farklılık yerine özünde sadece anlamsal farklılıkları yansıtır (Andersen, 1993). Örneğin; Bilkey ve Tesar (1977) ve Czinkota (1982), işletmelerin ihracata yönelim dürtüsünü, Çavuşgil (1980) ve Reid (1981)'den farklı yorumlamaktadırlar. Bilkey ve Tesar (1977) ve Czinkota (1982)'nın modellerinde, işletmeler ilk aşamada ihracata karşı ilgisizdir ve ancak ikinci aşamada kısmen ilgi duyarlar. Çavuşgil (1980) ve Reid (1981)'in modellerinde ise, işletmeler ilk aşamalarda bile ihracata karşı ilgili ve aktif birimler olarak görülürler. Yenilikle İlişkili Modeller, uluslararasılaşmayı başlatma mekanizmaları dışında Uppsala Modeli ile de benzerdirler. Çünkü özünde her iki model de yavaş ve aşamalı bir uluslararasılaşma öngörür.

İşletmelerin uluslararasılaşma davranışlarını kavramsal bir çerçeve içerisinde açıklamaya yönelik olarak geliştirilen geleneksel modellerin, çevresel koşulların değişimi neticesinde zaman içerisinde evirilerek, küresel doğan işletme modeline dönüştüğü görülmektedir. Küresel doğan işletme modeli, geleneksel modellere aykırı olarak işletmelerin kuruluşlarıyla beraber yabancı pazarlarda aktif hale gelebileceğini öngörür. Geleneksel modeller, hayatta kalmayı merkeze alarak işletmelerin zaman içinde yavaş ve sağlam adımlar atarak uluslararasılaştığını savunmuştur. Çünkü bu modellerde uluslararasılaşma, işletmenin örgütsel bilgi tabanına yönelik bir "şok" olarak görülüp, yabancı pazarlara erken girişin işletmenin hayatta kalmasını tehdit edeceğinden korkulmuştur. Küresel doğan işletme modeli ise uluslararasılaşma için bir seçim aracı olarak büyüme firsatlarını görür. Erken uluslararasılaşmanın olumlu sonuçlarına odaklanarak, tereddütlerin fırsat kaybına yol açacağını vurgular (Sapienza, Autio, George, \& Zahra, 2006).

Öncesinde büyük çokuluslu işletmelerin hâkimiyetinde görülen uluslararası ticaret ve doğrultusunda uluslararası işletmecilik, 1990'lı yıllarla birlikte küresel doğan işletme fenomeni ile değişime uğramıştır. Dünya çapında ortaya çıkan bu fenomen yaş, deneyim ve maddi kaynaklarına bakılmaksızın herhangi bir işletmenin aktif katılımcı olabileceği, uluslararası bir değişim sisteminin ortaya çıkmasını ima ettiği için yüreklendiricidir (Knight \& Çavuşgil, 2004). Küreselleşmenin bütünleştirici etkisi, bilgi, iletişim teknolojilerinde ve lojistik alanında yaşanan baş döndürücü gelişmeler sayesinde günümüz işletmeleri, kuruluşlarından itibaren 
küresel piyasalarda rekabet edebilecek yetenekler geliştirebilmektedirler. Bu doğrultuda küresel doğan işletmeler, yeni bir dönemi ifade etmektedir. Bu dönemde, ekonomik açıdan neredeyse küresel bir köy haline gelen dünyanın dört köşesindeki fikir, mal ve insanlar, sayılamayacak kadar çok sayıdaki küçük işletmeye doğru hareket etmektedir (Çavuşgil vd., 2011).

Küresel doğan işletme (born globals) kavramı, ilk kez Renny (1993) tarafindan hazırlanan McKinsey raporunda, Avustralya'daki hızlı uluslararasılaşan işletmeleri tanımlamak üzere kullanılmıştır. Rennie (1993), 300 Avustralya işletmesi ile gerçekleştirdiği araştırmasında, bu işletmelerin gelirlerinin 3/4 ünü yurt dış1 satışlarından elde ettiklerini ve kuruluşlarından ortalama iki yıl sonra ihracata başladıklarını tespit etmiştir.

Renny (1993)' nin ardından, bu özel işletme grubuna yönelik olarak 'küresel doğanlar” ifadesini kullanan çeşitli araştırmalar (Çavusgil, 1994; Freeman \& Cavusgil, 2007; Gabrielsson \& Kirpalani, 2004; Knight \& Çavuşgil, 1996; Knight, Madsen, \& Servais, 2004; Madsen \& Servais, 1997; Moen \& Servais, 2002) yanında, farklı kavramsal ifadelerde geliştirilmiştir. Nitekim uluslararası işletmecilik literatüründe, "Uluslararası Yeni Girişimler (Internationals New Ventures)" (Coviello, 2006; McDougall, Shane, \& Oviatt, 1994; Oviatt \& McDougall, 2005; Oviatt \& McDougall, 1994) "Küresel Başlayanlar (Global Start-ups)” (Hordes, Clancy, \& Baddaley, 1995); “Anında Uluslararasılaşanlar (Instant Internationals)” (Fillis, 2001); “Anında İhracata Başlayanlar (Instant Exporters)" (McAuley, 1999); "Erken Uluslararasılaşan İşletmeler (Early Internationalising Firms)” (Rialp, Rialp, \& Knight, 2005) gibi farklı ifadelere rastlanmaktadır (Berber vd., 2018).

Küresel doğan işletmeleri tanımlamaya yönelik olarak, alan yazında genellikle üç ortak ölçütten bahsedilmektedir. İlk ölçüt, bu işletmelerin küçük ve orta büyüklükte işletme niteliği taşımalarıdır (Knight \& Çavuşgil, 1996; Rennie, 1993). İkinci ölçüt, işletmelerin kuruluşları ile yabancı ülke pazarlarında önemli ölçüde gelir elde etmeye başlaması arasında geçen süredir. Literatürde hakim görüş, bu sürenin 3 yıl olduğu yönündedir (Freeman \& Çavuşgil, 2007; Karra \& Philips, 2004; Knight \& Çavuşgil, 1996; Madsen, Rasmussen, \& Servais, 2000; Rasmussan, Koed Madsen, \& Evangelista, 2001). Kullanılan üçüncü ölçüt ise, toplam satışlar içerisinde ihracatın payıdır. Bu payın da genellikle \% 25 olduğu (Karra \& Philips, 2004; Knight \& Çavuşgil, 1996; Madsen vd., 2000; Moen, 2002) ifade edilmektedir. Bu üç ölçütü aynı anda karşılayan işletmeler, küresel doğan işletme olarak kabul edilmektedir. 
$\mathrm{Bu}$ ölçütler doğrultusunda çalışmamızda, alan yazında genel kabul gören Knight ve Çavusgil $(1996,2004)$ tarafından yapılmış küresel doğan işletme tanımı benimsenmekte ve "kuruluşlarını izleyen ilk üç yıl içerisinde, toplam satışlarının en az yüzde 25'ini diğer ülke pazarlarından elde eden işletmeler”, küresel doğanlar olarak kabul edilmektedir.

\section{ULUSLARARASILAŞMADA AĞ YAKLAŞIMI}

Johanson ve Mattsson (1988) tarafından ilk kez ifade edilen "Uluslararasılaşmada Ağ Yaklaşımı”, iş ilişkilerinin işletmelerin büyümesi ve uluslararasılaşması üzerindeki etkisini vurgulamaktadır (Johanson \& Vahlne, 1992, 1990). Yaklaşıma göre; işletmelerin yeni uluslararası pazarlara girme başarısı, seçilen pazar ve onun kültürel özelliklerinden ziyade, bu pazarlarda geliştirdikleri ilişkilerine daha fazla bağlıdır (Johanson \& Mattsson, 1988). İşletmelerin ağındaki diğer aktörlerle (müşteriler, tedarikçiler, rakipler, finans kuruluşları, kamu kurumları, vb.) olan ilişkileri ve bu ilişkiler yoluyla eriştikleri (hammaddeler, ürünler, bilgi, fonlar, teknoloji, vb.), uluslararasılaşmalarında önemli rol oynar (Atlı \& Kartal, 2014).

Uluslararasılaşmada geleneksel modeller, 1970’lerin ortalarına kadar işletmelerin uluslararasılaşma davranışlarını açıklamakta uygun görülse de, bu dönemden sonra küreselleşmenin etkisiyle pazarların birbirlerine büyük ölçüde entegre hale gelmesiyle yetersiz kalmıştır (Fina \& Rugman, 1996). Uluslararasılaşmada ağ yaklaşımı ise bu yeni koşullarda, işletmelerin uluslararasılaşmasını açıklayabilecek alternatif model arayışı sonucunda ortaya çıkmıştır. Yaklaşım, geleneksel görüşleri reddetmemekle birlikte, uluslararasılaşmanın bu modellerde ifade edildiğinden çok daha karmaşık bir biçimde geliştiğini vurgulamaktadır. Buna göre birbiriyle bağlantılı değişim ilişkileri, dinamik ve geleneksel modellerde belirtildiğinden daha az yapılandırılmış bir biçimde gelişir. Taraflar arasındaki bilgi ve güven artışı, zaman içinde aktörler arasında daha büyük bir bağlılığa yol açar (Bell, 1995) ve aktörlere karşılıklı yararlar sağlar (Johanson \& Mattsson, 1988; Johanson \& Vahlne, 2003).

Geleneksel modellerin uluslararasılaşmayı tek taraflı bir süreç olarak gören bakışı ile kıyaslandığında ağ yaklaşımı, piyasaları birbiriyle bağlantılı iş ilişkileri ağı olarak görerek, uluslararasılaşmaya yönelik çok yönlü bir bakış açısı sunar (Johanson \& Vahlne, 1992). Uluslararasılaşmayı, işletme ile pazar arasında gelişen bir süreç olarak görmek yerine, bir ağ içinde bağımsız işletmeler arasında gelişen ilişkileri vurgular. $\mathrm{Bu}$ doğrultuda işletmenin uluslararasılaşma başarısı, yabancı pazarlarda kuracağı ileri ilişkilerle belirlenir (Coviello \& McAuley, 1999). Gelişimi için zaman gerektiren bu ilişkiler, uzun vadede karşılıklı güven 
oluşumu ve paylaşılan bilgi miktarının artışı ile pazara yüksek derecede bağlılık sağlar (Madsen \& Servais, 1997).

Uppsala Modeli' nin ilk versiyonunda (Johanson ve Wiedersheim-Paul 1975) ve daha sonra geliştirilmiş halinde (Johanson ve Vahlne 1990), uluslararasılaşmanın ilk aşamalarında işletmelerin aracı kullanmaları gerektiği, çünkü bu aşamada kendi iştiraklerini kurabilmek için gerekli kaynak ve bilgiye sahip olmadıkları vurgulanmıştır (Chetty \& Campbell-Hunt, 2004). Benzer şekilde küresel doğan işletmeler için alıcı, satıcı ve aracıları içeren uluslararası ağlara erişim kritik faktörler olarak görülmektedir (Knight \& Çavuşgil, 1996). Çünkü bu türden uzun vadeli ağ ilişkileri, bu işletmelere hızlı uluslararasılaşmada etkili olan pazar ve deneyimsel bilgiyi biriktirmek için beklemek yerine, faydalanmaları için hazır olarak sunar. Bu doğrultuda her iki görüş de, ağ ilişkilerinin uluslararasılaşmada işletmelerin kullandığı bir araç olduğunu göstermektedir (Chetty \& Campbell-Hunt, 2004).

\section{1. İşletmelerin Erken Uluslararasılaşmasını Açıklamada İş ve Sosyal A Ă İlişkileri}

Literatürde genel olarak ağ ilişkilerinin işletmelerin uluslararasılaşmasına yönelik olarak; yeni pazar firsatlarının tanımlanmasında (Chetty \& Blankenburg Holm, 2000; Coviello \& Munro, 1995; Ellis \& Pecotich, 2001; Harris \& Wheeler, 2005; Kontinen \& Ojala, 2011; Madsen \& Servais, 1997; Özgen \& Baron, 2007; Mort \& Weerawardena, 2006; Vasilchenko \& Morrish, 2011), yabancı pazar bilgisinin ediniminde (Chetty \& Blankenburg Holm, 2000; Coviello \& Munro, 1995; Harris \& Wheeler, 2005; Özgen \& Baron, 2007; Prashantham \& Dhanaraj, 2010; Riddle \& Gillespie, 2003) ve kaynaklara erişim sağlanmasında (Chetty \& Wilson, 2003; Gulati \& Gargiulo, 1999; Hoang \& Antoncic, 2003; Nummela, 2002; Tang, 2011) önemli rol oynadığı belirtilmektedir.

A $\breve{g}$ ilişkileri, hem bireyler arasındaki sosyal ilişkileri hem de kuruluşlar arasındaki etkileşimleri ifade etmektedir (Melin, 1987). Bu doğrultuda girişimcilikte birbirinden farklı iki ağ yaklaşımı olduğu kabul edilir. İlki, işletme kurucularını odak olarak alan ve girişimcilerin bireysel ilişkilerini içeren kişisel ağlar; ikincisi, işletmeyi odak olarak kabul eden ve kolektif ilişkileri içeren örgütsel ağlardır (Brüderl \& Preisendörfer, 1998; Hoang \& Antoncic, 2003; O’Donnel vd., 2001). Kişisel ve örgütsel ağlar, "sosyal ilişkiler-iş ilişkileri” (Agndal \& Chetty, 2007), "sosyal ağlar-stratejik ağlar" (Chetty \& Wilson, 2003), "gayri resmi ağlar-resmi ağlar" (Birley, 1985; Johannisson, 1986), "kişisel ağlar-genişletilmiş ağlar” (Dubini \& Aldrich, 1991) gibi farklı terimlerle de birbirlerinin yerine kullanılabilmektedir. Bu çalışmada ise, Türkçe 
anlamı daha iyi yansıttığı düşünülen "sosyal ağ ilişkisi-iş ağı ilişkisi” kavramlarının kullanımı tercih edilmektedir.

Sosyal ağ ilişkileri; "bireyin” aktör olarak odak kabul edildiği ilişkilerdir. İlişki, bireyin katılımı olmadan var olamaz (Agndal \& Chetty, 2007). Bu kapsamda sosyal ağ ilişkileri, girişimciler tarafından kişisel olarak yaratılan ve onlarla ilgili olan ilişkilerdir (Melen \& Nordman, 2007). Çalışmamızda, odak aktör olarak girişimcinin; aile üyeleri, arkadaşları ve meslektaşları ile ilişkileri (Birley, 1985; Chetty \& Wilson, 2003) sosyal ağ ilişkileri kapsamında değerlendirilmektedir. İş ağı ilişkileri ise, kurumsallaşmış bir ilişki türüdür. Odak aktör olarak "kuruluş" kabul edilir. İlişki, belirli bireylere bağlı değildir. Bu ilişkiler kişiler tarafindan değil işletmeleri tarafından yaratıldıklarından, işletmeyle ilişkilendirilir ve diğer kişilere devredilebilirler (Melen \& Nordman, 2007). Bu çalışmada iş ağlarının tanımlanmasında; Emerson (1981)'ın, “her bir değişim ilişkisinin kolektif aktörler olarak kavramsallaştırılan işletmeler arasında gerçekleştiği, iki veya daha fazla bağlantılı iş ilişkileri kümesi” (Anderson, Hakansson, \& Johanson, 1994, s. 2) tanımı benimsenmektedir. Belirtilen kolektif aktörler ise; müşteriler, dağıtıcılar, rakipler, tedarikçiler ve devlet kurumları (Johanson \& Mattsson, 1988; Sharma \& Johanson, 1987) gibi aktörleri içermektedir.

A $\breve{g}$ yaklaşımı ve analizlerinin, uluslararası girişimcilik araştırmaları için güçlü bir çerçeve oluşturduğu (McDougall \& Oviatt, 2003), hatta uluslararası girişimcilik araştırmalarının temelini teşkil ettiği (Coviello, 2006) öne sürülmektedir. Mevcut küresel doğan işletme araştırmaları hızlı bir uluslararasılaşma sürecini yönetme yolunun, ihtiyaç duyulan kaynaklara erişmek için ağların kullanılması suretiyle gerçekleştiğini göstermiştir (Coviello \& Munro, 1997). Çeşitli araştırmacılar bu firmaların erken uluslararasılaşmasını, dış pazarlardaki faaliyetlerinin ağ ilişkileri ile etkileşimler yoluyla gerçekleştiği, ağlar üzerinden bir öğrenme meselesi olarak görmüşlerdir (Sharma \& Blomstermo, 2003). Karra ve Philips (2004)'in, İstanbul'da kurulmuş, deneyim ve kaynak eksikliğine rağmen kuruluşuyla birlikte tamamen ihracata yönelmiş küresel doğan bir işletmeyi inceledikleri çalışmaları, ağ ilişkilerinin ülkemiz ekseninde de uluslararası girişimcilik için önemli dört başarı faktöründen biri olduğunu göstermiştir. Ancak bu öneme rağmen yerli literatür yanında yabancı literatürde de, küresel doğanların uluslararasılaşmasını ağ perspektifinden inceleyen çalışmaların sınırlı sayıda olması bir araştırma boşluğu olarak dikkat çekmektedir (Andersson \& Wictor, 2003; Bembom \& Schwens, 2018; Coviello, 2006; Sharma \& Blomstermo, 2003).

Uluslararasılaşmada ağ yaklaşımı, ilk zamanlarda yalnızca işletmeler arasında gelişen ilişkileri konu edinse de, zaman içinde birey düzeyinde gelişen sosyal ağ ilişkileri de yapılan 
araştırmaların kapsamına dâhil edilmiştir. Nitekim konu ile ilgili olarak sosyal ağ yaklaşımı perspektifinden yapılmış bir dizi araştırma mevcuttur (örn: Andersen, 2006; Andersson \& Wictor, 2003; Ellis, 2000; Ellis \& Pecotich, 2001; Harris \& Wheeler, 2005; Komulainen, Mainela, \& Tähtinen, 2006; Manolova, Manev, \& Gyoshev, 2010).

Çeşitli araştırmalarla, işletmelerin hızlı uluslararasılaşmasında ağ ilişkilerinin kolaylaştırıcı rolü ispatlanmakla birlikte, sosyal ve iş ağı ilişkilerinin hangisinin bu süreçte en etkili olduğu konusunda ise alan yazında tartışmaların sürdüğü ve bir uzlaşının sağlanamadığı görülmektedir (Melen \& Nordman, 2007). Bir taraftan güçlü uluslararası iş ağı ilişkilerinin başarılı yeni uluslararası girişimlerin en önemli özelliğinden biri olduğu (Oviatt \& McDougall, 1994) ifade edilirken, diğer taraftan girişimcinin sosyal ă̆ ilişkilerinin erken uluslararasılaşmada kritik bir soruşturma noktasını temsil ettiği (Zain \& Ng, 2006; Andersen, 2006; Ellis, 2000; Harris \& Wheeler, 2005; Komulainen, Mainela, \& Tähtinen, 2006; Zhou, Wu, \& Luo, 2007) öne sürülmektedir.

Manolova, Manev ve Gyoshev (2010), Bulgaristan'da yeni kurulmuş KOBİler üzerinde gerçekleştirdikleri araştırmalarında, girişimcilerin sosyal ağ ilişkilerinin işletmelerinin uluslararasılaşması üzerinde olumlu bir etkiye sahip olduğunu; iş ağı ilişkilerinin ise aynı etkiyi göstermediğini bulmuşlardır. Karra ve Philips (2004), ağların genellikle belirsiz ortamlarda yüksek derecede güven sağlayan, etnik veya diğer sosyal bağlar üzerine kurulu olduğunu ifade etmektedirler. Araştırmacılara göre bu bağlar, sosyal destek sağlamanın yanında aynı zamanda iletişim ve değişim kanalları olarak da işletilirler. Etkileşim ve iletişim şansını öğrenme ve arttırma firsatları sunar ve ağ dışındakiler için elde edilmesi mümkün olmayan bir dereceye kadar desteklerler (Karra \& Philips, 2004). Masango ve Marinova (2014), Güney Afrikalı erken ve hızlı uluslararasılaşan 10 küçük işletmenin sınır ötesi faaliyetlerinin temelini oluşturan ilişkilerin kaynağını, temel özelliklerini ve özel işlevleri ile gelişim süreçlerini araştırmışlardır. Araştırmadan elde edilen bulgular, erken ve hızlı uluslararasılaşan bu işletmelerin uluslararasılaşma davranışlarının ağırlıklı olarak güçlü bilgi temelli temaslardan oluşan ve işletmenin kuruluşu öncesinde girişimcileri tarafından oluşturulmuş kişiler arası (sosyal) ağ ilişkilerine dayandığını ortaya çıkarmıştır. Ayrıca bu sosyal ağ ilişkilerinin, işletmelerin sınır ötesi faaliyetlerine öncülük eden örgütler arası ağ ilişkilerinin (iş ağları) kurulması için de temel oluşturduğu bulunmuştur (Masango \& Marinova, 2014). Benzer şekilde Vasilchenko ve Morrish (2011), 4 Yeni Zelandalı yüksek teknoloji firmasının hızlı uluslararasılaşmasını kolaylaştırmada fırsatların keşfedilmesi ve kullanılması perspektifinden, sosyal ve iş ağlarının rolünü araştırmışlar ve uluslararasılaşmanın erken aşamalarında en çok sosyal ağların etkili 
olduğu sonucuna ulaşmışlardır. Araştırmada, erken aşamada yabancı pazara giriş kararı ve pazar seçiminde sosyal ağların etkili olduğu ve bazı durumlarda bu sosyal ağların, sonraki uluslararasılaşma sürecinde etkili olan iş ağlarına dönüştüğü görülmüştür (Vasilchenko \& Morrish, 2011).

Diğer taraftan Chetty ve Wilson (2003), Yeni Zelandalı işletmeler üzerinde gerçekleştirdikleri araştırmalarında hızlı uluslararasılaşmanın iş ağlarına daha erken odaklanmayla desteklendiğini, sosyal ağ ilişkilerinin yoğun olarak kullanımının ise daha yavaş bir uluslararasılaşma sağladığı bulgusuna ulaşmışlardır. Coviello ve Munro (1995)'nun Yeni Zelandalı 4 küresel doğan işletme nezdinde yürüttükleri araştırmaları da, bu işletmeler için uluslararasılaşmanın ilk aşamalarında iş ağlarının özellikle önemli olduğu sonucuna işaret etmektedir. Yine Yeni Zelandalı 12 KOBİ ile gerçekleştirdikleri araştırmalarında Chetty ve Campbell-Hunt (2004), hızlı uluslararasılaşma ile iş ağları ilişkisini incelemişler; iş ağlarının yeni firsatlar, teknoloji, pazar bilgisi ve enformasyon sağlayarak, işletmelerin aşamalı uluslararasılaşması yerine hızla uluslararasılaşmalarına olanak tanıdığını göstermişlerdir. Araştırmada ayrıca potansiyel uluslararası ortakları tanımlamak ve müteakip işbirliklerinden fayda sağlamak için, ağ ortaklarının önemli bir kolaylaştırıcı olduğu bulunmuştur (Chetty \& Campbell-Hunt, 2004).

Ibeh ve Kasem (2011)'in, Suriyeli 3'ü küresel doğan olmak üzere 6 işletme ile gerçekleştirdikleri araştırmalarında ise, uluslararasılaşmada hem sosyal hem de iş ağlarının önemli olduğuna işaret edilmektedir. Bulgulara göre, sosyal ağlar başlangıç aşamasında daha etkili olurken, iş ağları sonraki aşamalarda baskın hale gelmiştir. Aynı doğrultuda Eberhard ve Craig (2013) tarafından 1304 Avustralyalı KOBİ üzerinde yürütülen araştırmada, küresel doğan işletmelerde hem sosyal, hem de iş ağı ilişkilerinin her ikisinin de uluslararasılaşmayı olumlu yönde etkilediği bulgusuna ulaşılmıştır. Benzer bulgular Melen ve Nordman (2007) tarafından da sunulmuştur. Araştırmacılar, İsveçli küresel doğan bir bioteknoloji firması üzerinde gerçekleştirdikleri örnek olay çalışmasında, sosyal-iş ağ ilişkilerinin göreceli öneminin küresel doğan bir işletmenin farklı aşamalarında değişim gösterdiğini tespit ederek, her iki ağ türünün de uluslararasılaşmada önemli olduğu sonucuna ulaşmışlardır (Melen \& Nordman, 2007). Bu bulgular paralelinde Rialp, Rialp ve Knight (2005), erken uluslararasılaşma fenomenine yönelik olarak 1993 ile 2003 yılları arasında yapılan 38 araştırmayı inceledikleri çalışmalarında, hem kişisel hem de iş ağı ilişkilerinin kullanımının, küresel doğan firmalar nezdinde erken uluslararasılaşmayı sağladığı ve kolaylaştırdığı sonucuna varmışlardır. 
Riddle ve Gillespie (2003) ise, Türkiye örnekleminde gerçekleştirdikleri ampirik araştırmalarında, tekstil sektöründe faaliyet gösteren 250 işletmenin ihracat bilgisine ulaşmada ağ ilişkilerini nasıl kullandıklarını araştırmışlardır. Gerçekleştirilen anket çalışması sonucunda ulaşılan bulgular, gayri resmi sosyal bağların özellikle arkadaşlık ve aile bağlarının, bu sektördeki yeni girişimci firma sahipleri için kritik bilgi kaynakları olduğunu göstermiştir. Arkadaşlık ve aile bağları gibi gayri resmi bağlar, yeni girişimci firma sahipleri nezdinde özellikle teknolojik gelişmeler ve tedarikçiler hakkında bilgi aramak açısından, bilgi ediniminde önemli rol oynamaktadır. Bunun yanında resmi bağ olarak Türk giyim endüstrisindeki girişimcilere ihracat bilgisi sağlayan ve firma sahiplerinin ağında kolayca erişilebilir olan tek resmi kurumun, İstanbul Tekstil ve Konfeksiyon İhracatçıları Birliği (İTKİB) olduğu tespit edilmiştir.

Türkiye örnekleminde gerçekleştirilen diğer bir ampirik araştırmada Baskici ve Ercil (2018), Ankara ilinde imalat, bilişim, enerji gibi çeşitli sektörlerde faaliyet gösteren 90 işletmenin, uluslararasılaşmada kullandıkları ăg oluşturma mekanizmalarının ortaya çıkarılmasını amaçlamışlardır. Örneklemi oluşturan işletmelerin 19'unun (\% 21,1) küresel doğan niteliği taşıdığı araştırmada, işletmelerin ilk ihracatlarında hangi ağlardan faydalandıkları sorgulanmıştır. Buna göre, küresel doğanların uluslararasılaşmada yaygın olarak $(\%$ 63,2) stratejik olarak kendilerinin oluşturdukları ilişkilerken yararlandığı, ikinci sırada ise mevcut tanıdıkları $(\% 31,6)$ ile olan sosyal ilişkilerini kullandıkları ortaya çıkarılmıştır. Ayrıca araştırma sonucunda küresel doğan işletmelerden hiçbirinin, ilk ihracatlarında kamu kurumlarının destekleyici faaliyetlerinden yararlanmadıkları tespit edilmiştir.

\section{ARAŞTIRMANIN METODOLOJISİ}

\subsection{Araştırmanın Amacı ve Önemi}

Bu çalışmanın temel amacı, erken uluslararasılaşmada ağ ilişkilerinin rolünün Türkiye ekseninden küresel doğan bir işletme örneği üzerinden ortaya konulmasıdır. Bu amaç doğrultusunda araştırmada, örnek olay çalışması ile Bursa ilinde tekstil sektöründe faaliyet gösteren Turkuaz Yatak'ın erken uluslararasılaşma süreci incelenmekte ve ağ ilişkilerinden bu süreçte sağlananların tespit edilmesi beklenmektedir.

Turkuaz Yatak, 2015 yılı 4. KOSGEB KOBİ ve Girişimcilik Ödülleri Yarışmasında Küresel doğan girişimci finalisti olmuş, başarısı tescilli küresel doğan bir Türk işletmesidir. Çalışmada işletmenin kuruluş öncesinden başlayarak, günümüze kadarki faaliyetlerine yer 
verilmektedir. Araştırmanın küresel doğan işletmeler özelinde Türkiye'deki mevcut araştırma boşluğunu hedef alarak, alan yazına katkı sağlaması bakımından önemli olduğu düşünülmektedir.

\subsection{Araştırma Yöntemi ve Deseninin Seçimi}

Türkiye özelinde ağ ilişkilerinin erken uluslararasılaşmadaki rolünün keşfedilmesini amaçlayan bu çalışmada, nitel araştırma yöntemine başvurulmuştur. Araştırmacıların bu yönteme yönelim nedeni, Türkiye ekseninde erken uluslararasılaşma olgusunun, ağ ilişkileri perspektifinden derinlemesine anlaşılması gerekliliğidir. Çünkü nitel araştırmanın temelinde, keşfedilmek istenen temel bir olgu (konu) vardır (Creswell, 2017). Nitel yöntemler araştırmacıya, incelenen olguyu (erken uluslararasılaşma) kendi bağlamında ve bütüncül olarak değerlendirme imkânı sunarlar. Bu bağlamda nitel araştırma; "gözlem, görüşme ve doküman analizi gibi nitel veri toplama yöntemlerinin kullanıldığı, alg1 ve olayların doğal ortamlarında gerçekçi ve bütüncül olarak ortaya konmasına yönelik nitel bir sürecin izlendiği araştırma" olarak tanımlanır (Yıldırım \& Şimşek, 2016, s. 41). Nitel araştırmalarda kullanılabilecek çeşitli araştırma desenleri bulunmaktadır. Araştırmamızda bu desenlerden, örnek olay çalışmasının kullanımı tercih edilmiştir.

Örnek olay çalışması, Yin (1994, s. 13) tarafından, "güncel bir olguyu gerçek yaşam bağlamında araştıran ampirik bir araştırma" olarak tanımlanmaktadır. Bu desen araştırmacıya bir olaya müdahale etmeden derinlemesine inceleme, anlama ve çıkarımlarda bulunma firsatı sunar (Creswell, 2014; Yin, 2014). "Nasıl” veya "neden” sorularına cevap arandığında ve araştırmanın odağı gerçek yaşam bağlamında güncel bir olguyu içerdiğinde, örnek olay çalışması sıklıkla tercih edilmektedir (Yin, 1994, s. 1). Araştırma sorunsalımız, erken uluslararasılaşma gibi "güncel bir olguda", ağ ilişkilerinin "nasıl" bir rol oynadığının keşfi olduğundan, örnek olay çalışması araştırmamıza en uygun desen olarak görülmüştür. Bu desen uluslararasılaşma sürecine anket verisiyle sağlanması mümkün olmayan ölçüde, zenginlik ve derinlik kazandırmasından dolayı uluslararasılaşma araştırmalarında sıklıkla kullanılmaktadır (Coviello \& Munro, 1997).

\section{3. Örnekleminin Belirlenmesi}

Nitel araştırmalarda örneklemin belirlenmesinde, derinlemesine veri elde etmek amacıyla genellikle amaçlı örnekleme yöntemleri kullanılmaktadır. Patton (1990, ss. 169-181) amaçlı örnekleme yöntemlerini; aşırı veya aykırı durum örneklemesi, maksimum çeşitlilik örneklemesi, benzeşik örnekleme, tipik durum örneklemesi, kritik durum örneklemesi, kartopu 
veya zincir örnekleme, ölçüt örnekleme, doğrulayıcı veya yanlışlayıcı örnekleme ve kolay ulaşılabilir durum örneklemesi olarak sıralamaktadır. $\mathrm{Bu}$ yöntemlerden ölçüt örnekleme, önceden belirlenmiş bazı ölçütleri karşılayan durumları incelemek yoluyla bilgi yönünden zengin durumların anlaşılmasını sağlamaktadır (Patton, 1990, s. 176). Faydalanılan ölçütler, araştırmacı tarafından oluşturulabildiği gibi önceden hazırlanan bir ölçüt listesi de kullanılabilir (Yıldırım \& Şimşek, 2016, s. 122).

Çalışmamızda amaçlı örnekleme yöntemlerinden ölçüt örnekleme yöntemi kullanılarak, örneklem seçiminde literatürde genel kabul gören "küresel doğan işletme olma” ölçütlerinden faydalanılmıştır. Bu doğrultuda kuruluşunu müteakip ilk üç yıl içerisinde toplam satışlarının en az yüzde 25'ini diğer ülke pazarlarından elde etme (Knight \& Çavusgil, 2004; Knight \& Çavuşgil, 1996) koşulu aranmıştır. Bu ölçütlere ek olarak, Türkiye'deki başarılı küresel doğan işletmeleri düzenlediği bir yarışma yoluyla ödüllendiren KOSGEB'in bu yarışmadaki değerlendirme ölçütleri de dikkate alınmıştır.

KOSGEB, 2012 yılından beri düzenlediği “KOBİ ve Girişimcilik Ödülleri Yarışması” ile başarılı işletmeleri çeşitli kategoriler altında ödüllendirmektedir. 2019 yılına kadar üç temel kategori altında düzenlenen yarışmada, "Yı1ın Başarılı Girişimci Ödülleri” bu kategorilerden biridir. İlgili kategoriye başvuru için aranan genel şart işletmelerin "son üç mali yıl içinde kurulmuş, geleceğe dair büyüme stratejileri geliştirmiş, istihdam ve net satış hasılatı tutarında artan bir performans sağlayarak, girişimciler için rol model oluşturmuş" olmalarıdır. "Yılın Başarılı Girişimci Ödülleri” kategorisi 2019 yılına kadar, kendi içinde dört alt kategoriye ayrılmıştır. "Yılın Küresel Doğan Girişimcisi Ödülü” ise bu alt kategorilerden biridir. Bu alt kategoride değerlendirilecek işletmelerin yukarıda belirtilen genel şartları sağlamanın yanında, kuruluş yılı itibariyle toplam net satış hasılatı tutarı ortalamasının en az yüzde 25 'ini ihracat gelirlerinden elde etmesi ve uluslararası ortaklık, bayilik, proje vb.' de yer alarak uluslararası işbirliği yapmış olmaları (Kobi ve Girişimcilik Ödülleri Uygulama Esasları) beklenmektedir.

Örneklem belirlenmesi sürecinde KOSGEB ile iletişime geçilerek, "Yı1ın Küresel Doğan Girişimci Ödülü” kategorisinde bugüne kadar finalist olmuş, Türkiye çapında toplam 25 işletmenin bilgileri elde edilmiştir. Bu işletmelerden 13 tanesinin Marmara Bölgesinde faaliyet gösterdiği tespit edilmiştir. İşletmelerle iletişim kurulmuş ve araştırmamıza katılmayı kabul eden Turkuaz Yatak ile çalışma gerçekleştirilmiştir. Turkuaz Yatak, 4. KOBİ ve Girişimcilik Ödülleri, "Yılın Küresel Doğan Girişimci” kategorisinde 2015 yılında finalist olmuş, bu doğrultuda erken uluslararasılaşma başarısı KOSGEB tarafından tescillenmiş küresel doğan bir işletmedir. 


\subsection{Araştırmanın Kapsam ve Sınırlılıkları}

Araştırmamızda örnek olay olarak incelenen Turkuaz Yatak'ın “erken uluslararasılaşma süreci” ele alınmaktadır. Araştırma, ilgili literatür çerçevesinde bu sürecin tetikleyicisi olarak görülen “ağ ilişkileri” açısından erken uluslararasılaşmanın incelenmesini kapsamaktadır. Yin'e (2003) göre, amaçlanan tipik bir durumun (erken uluslararasılaşma) koşullarını anlamak olduğunda, daha büyük şirketler grubundan seçilen temsili veya tipik bir durum kullanmak uygundur. Tek vakalardan öğrenilen dersler, ortalama bir organizasyonun aynı alandaki deneyimleri hakkında bir şeyler söylemek için kullanılabilir. Bu doğrultuda araştırmamızda, Melen ve Nordman (2007)'ın da araştırmalarında benimsedikleri gibi tek bir örnek olay incelemesi yapılarak, tipik bir vaka aracılığıyla derinlemesine analiz yapılması amaçlanmıştır.

Araştırmanın en önemli kısıtı, Türkiye'deki küresel doğan işletmelerin uluslararasılaşmasını tek bir işletme üzerinden ele almasıdır. $\mathrm{Bu}$ nedenle sonuçların Türkiye'deki tüm küresel doğan işletmelere genellenebilmesinin mümkün olmadığının bir sınırlılık olarak belirtilmesi önem arz etmektedir. Öte yandan nitel araştırmalarda amaçlanan, nicel araştırmalarda olduğu gibi sonuçların istatistiki olarak bir evrene genellenmesi değildir. Örnek olay çalışmalarında bir örnek olaya ilişkin ulaşılan sonuçların, benzer durumların anlaşılmasına yönelik örnek ve deneyim oluşturması beklenmektedir (Yı1dırım \& Şimşek, 2016).

\subsection{Araştırmada Kullanılan Veri Toplama Yöntemleri}

Araştırma verilerinin toplanmasında, temel olarak yüz yüze görüşme yöntemi kullanılmıştır. Nitel araştırmalarda en sık kullanılan veri toplama yöntemleri görüşme, odak grup görüşmesi, gözlem ve doküman incelemesidir (Yıldırım \& Şimşek, 2016). Araştırmada kullanılan yarı yapılandırılmış görüşme sorularının hazırlanma sürecine, detaylı bir literatür araştırması eşlik etmiştir. Bu süreçte Greve (1995), Harris ve Wheeler (2005) ve Akhter (2013) gibi araştırmacıların çalışmalarından faydalanılmıştır. Sorular, uluslararası işletmecilik ve nitel araştırma yöntemleri uzmanlarının görüşleri doğrultusunda nihai hale getirilmiştir.

Görüşme, araştırma konusu ile ilgili kilit bilgi kaynağı olarak görülen girişimci Alper Emre Özay ile 7 Kasım 2018 tarihinde yapılmış ve 92 dakika sürmüştür. Katılımcı, görüşmeci tarafından deneyimlerini paylaşmaya ve bu sayede araştırma sorularının derinlemesine anlaşılmasına teşvik edilmiştir. Veri kaybını önlemek amacıyla katılımcının onayı doğrultusunda, yapılan görüşmenin ses kaydı alınmıştır. 
Örnek olay çalışmalarında veri güvenirliğini artırmak amacıyla çoklu veri kaynaklarının kullanımı tavsiye edilmektedir (Patton, 1990; Yin, 2003). Araştırmamızda veri güvenirliğini artırmak amacıyla, görüşme sırasında ve sonrasında tutulan saha notlarından yararlanılmıştır. Görüşmecinin tuttuğu bu notlar sonradan unutulması mümkün olan, özellikle de katılımcının beden dili ile ilgili detayları ve görüşmeciye $o$ an için önemli gelen anahtar kelimeleri muhafaza etmeyi sağlamaktadır (Seggie \& Bayyurt, 2015).

\subsection{Veri Analizi}

Nitel araştırmalarda veri analizi, nitel verilerin nicel hale getirilmesi değildir. Nitel analiz, ham verilerdeki kavram ve ilişkilerin keşfedilerek, açıklayıcı hale getirildiği bir yorumlama sürecidir (Strauss \& Corbin, 1998). Verilerin analize hazırlanması aşamasında, yapılan görüşmenin ses kaydı transkripsiyon işlemine tabi tutulmuştur. İşlem sonucunda metne dönüştürülen görüşme verisi, görüşme sırasında ve sonrasında görüşmeci tarafından tutulan saha notları ile birleştirilmiştir. Bu ikili kaynaktan elde edilen veriler, örnek olay işletmesine ilişkin bulguların oluşturulmasında kullanılmıştır. Oluşturulan metin araştırma katılımcısının onayına sunularak, onayı alınmıştır.

Araştırmadan elde edilen verilerin çözümlenmesi sürecinde, Strauss ve Corbin (1990) doğrultusunda Yıldırım ve Şimşek (2016) tarafından önerilen, betimsel analiz ve içerik analizi teknikleri birlikte kullanılmıştır. Betimsel analiz verilerin önceden belirlenmiş temalar doğrultusunda özetlenerek yorumlanmasını sağlarken; içerik analizinde ise veriler önce kavramsallaştırılmakta, ardından mantıklı bir biçimde düzenlenerek açıklayıcı temalar altında toplanmaktadır. Diğer bir deyişle verileri açıklayabilecek kavram ve temaların belirlenmesini içeren ve bu doğrultuda betimsel analizden daha derin olan içerik analizi, betimsel analiz sırasında fark edilemeyen kavram ve temaların ortaya çıkarılmasını sağlayabilmektedir (Yıldırım \& Şimşek, 2016).

Araştırmamızda ağ ilişkilerinin türünün sosyal ve iş ağı ilişkileri temelinde, literatürde ifade edilen ölçütler yoluyla sınıflandırılmasında betimsel analizden yararlanılmıştır. İçerik analizi ise ilgili işletme nezdinde ağ ilişkilerinin uluslararasılaşmaya yönelik sağladıklarının belirlenmesinde kullanılmıştır. Gerçekleştirilen içerik analizinde görüşmeci tarafından veriler defalarca okunarak kodlanmış, oluşturulan kodlar sınıflandırılarak açıklayıcı temalara ulaşılmıştır. Sürecin daha sistemli olarak yürütülebilmesi amacıyla, bilgisayar destekli nitel veri analizi yazılımlarından biri olan Nvivo 12'den yararlanılmıştır. Ortaya çıkan temalar ve bu 
temaları oluşturan kod listesi, ikinci araştırmacı tarafından da değerlendirilerek, her iki araştırmacının ortak görüşleri doğrultusunda nihai hale kavuşturulmuştur.

\subsection{Verilerin Geçerliği ve Güvenirliği}

Nitel araştırmalarda geçerlik ve güvenirliğe ilişkin çeşitli önlemler alınması gereklidir. $\mathrm{Bu}$ doğrultuda araştırmamızda, geçerliği ve güvenirliği sağlamak amacıyla aşağıda belirtilen önlemler alınmıştır:

○ Temel veri kaynağı olarak kullanılan görüşme verisi yanında yardımcı veri kaynağı olarak, araştırmacı tarafından tutulan saha notları kullanılmıştır. Görüşmeci tarafından girişimcinin tutum ve davranışları, görüşme ortamının fiziksel koşulları ve görüşme sonrasında edinilen izlenimlerin kaydedildiği saha notları, analiz sırasında bir yardımcı kaynak olarak kullanılmıştır.

○ Yapılan görüşme, veri kaybını engellemek ve ispat amaçlarıyla, katılımcının onayı alınarak ses kayıt cihazı ile kayıt altına alınmıştır.

○ Veri toplama öncesi ve sırasında detaylı bir literatür araştırması gerçekleştirilmiştir.

○ Transkripsiyon işlemi sonrasında metin haline dönüştürülen görüşme verisinde yeterince anlaşılır olmayan hususlar, katılımcıyla yapılan telefon görüşmesi yoluyla açıklığa kavuşturulmuştur. Bu doğrultuda son haline getirilen metin, teyidi alınmak üzere görüşmeciye gönderilmiştir. Alınan teyit sonrasında veri analiz süreci başlatılmıştır.

\section{BULGULAR: Turkuaz Yatak'ın Kuruluş Ve Uluslararasılaşmasının Gelişimi $^{3}$}

Turkuaz Yatak, 2012 yılının Ocak ayında Bursa'da kurulmuştur. Mobilya ve tekstil sektörlerinde faaliyet gösteren işletmede yatak kılıfı, yatak, baza, başlık ve setleri üretilmektedir. Girişimci Alper Bey, ailesinin geçmiş sektör tecrübeleri ışı̆̆ında ve ağ ilişkileri yardımıyla küresel doğan bir işletme yaratmış, genç bir endüstri mühendisidir. Kuruluşundan beri satışlarının tamamını yabanıı pazarlara gerçekleştiren Turkuaz'ın bu başarısı BTSO, UHKİB, KOSGEB gibi çeşitli kurumlardan aldı̆̆ı ödüllerle taçlandırılmıştır. Tablo 1'de işletmenin kısa bir tanıtımı yer almaktadır.

\footnotetext{
3 Örnek olay bulgularının ifade edilmesinde görüşülen kişinin isteği üzerine, bazı kişi ve kuruluşların gerçek isimleri yerine takma isim kullanılmıştır.
} 
Tablo 1. Turkuaz Yatak'ın Kisa Tanıtımı

\begin{tabular}{|c|c|c|c|}
\hline $\begin{array}{c}\text { Kuruluş } \\
\text { Yılı }\end{array}$ & $\begin{array}{c}\text { Çalışan } \\
\text { Sayısı }\end{array}$ & $\begin{array}{c}\text { İhracatın Tüm } \\
\text { Satışlara Oranı }\end{array}$ & \multicolumn{1}{c|}{ Alınan Ödüller } \\
\hline 2012 & 110 & $100 \%$ & $\begin{array}{l}\text { * BTSO Ekonomiye Değer Katanlar, En Başarilı } \\
\text { Kobiler Ödülü (2015) }\end{array}$ \\
$\begin{array}{l}\text { * 4.KOSGEB Kobi ve Girişimcilik Ödülleri, Başarı } \\
\text { Sertifikas1 (2015) }\end{array}$ \\
$\begin{array}{l}\text { *UHKiB 2015 Y111 İhracat Y11dızları, Hazır Giyim ve } \\
\text { Konfeksiyon Sektörü, Bronz Başarı Ödülü }\end{array}$ \\
\hline
\end{tabular}

Mevcut durumda işletme Almanya, Hollanda, Polonya, Belçika, İsrail ve ABD pazarlarına ürün satışı gerçekleştirmektedir. Şekil 1.'de işletmenin faaliyet gösterdiği pazarlar ve bu pazarlara yaptığı satışlarının tüm satışlarına oranı görülmektedir.

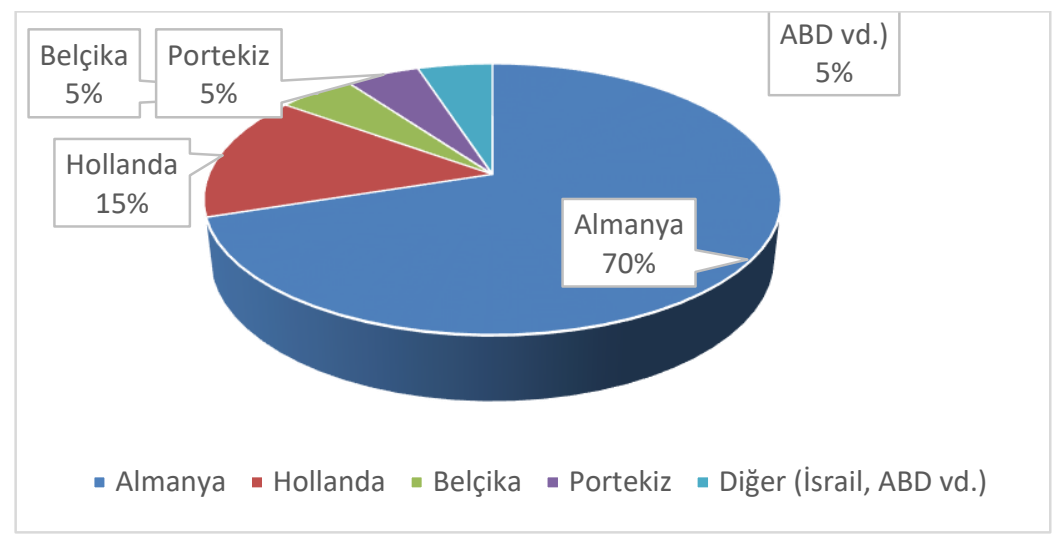

Şekil 1. Faaliyet Gösterilen Pazarlar ve İhracat Oranları

Buna göre, en büyük pazar olan Almanya'ya yapılan satışların tüm satışlar içerisindeki pay1 \% 70 dir. Bu oranı Hollanda pazarı \% 15, Polonya \% 5, Belçika \% 5 ve diğer pazarlar (İsrail, ABD vd.) $\% 5$ oranı ile izlemektedir.

Turkuaz Yatak'ın temelleri, Alper Bey'in dedesinin Almanya'ya Mercedes'te çalışmak amacıyla gidişi ve bu sayede orada bir çevre edinmesine kadar uzanmaktadır. Ailenin sahip olduğu sektör tecrübesi ise 1980'li yılların sonlarına dayanmaktadır. 1989 yılında Alper Bey’in babası, amcası ile birlikte önceleri sadece nevresim takımı ihracatı yapan, sonrasında buna havluyu da ekleyen ve daha çok dış piyasaya yönelik olarak çalışan Alfa Dış Ticaret'i kurarlar. Kısa sürede başarılı bir trend yakalamalarına rağmen işletme, 1994 yılındaki ekonomik krizle birlikte faaliyetlerine son vermek durumunda kalır. Ortaklıklarını sonlandıran baba ve amcanın ayrılık süreci sonrasında 1999 yılında, girişimcinin babası (Tb) tarafindan Beta Grup adı altında 
çekirdek aileye ait ilk işletme kurulur. Yükselen bir başarı grafiği ile devam eden grup 2006 yılına gelindiğinde, 5 işletme ve toplam 450 civarında çalışana sahiptir. Ancak aynı yıl grubun lokomotifi olan fabrikada çıkan talihsiz yangın, hızlı bir çöküşü de beraberinde getirir.

Maddi ve manevi olarak yaşanan zor günler sonrasında Alper Bey, askerlik ve eğitimini tamamlayarak 2008 yılı itibariyle tam zamanlı olarak işletmelerinde çalışmaya başlar. Tekstil mühendisi olan kardeşi Hilal Hanım (Th) ile birlikte kendilerini tamamen işletmelerine adarlar. Tüm kadro yenilenip, üçüncü şahıslara olan borçlar ödenir. Yaşadıkları zorluklar karşısında hem demoralize olan hem de hırslanan iki kardeş, 2009 yılının başında Gama Mobilya adı altında yeni bir işletme kurarak, bu işletmeye iki yıllık bir finans ortağı bulurlar. Aile çevresinden eski bir tanıdıkları olan (Tf) ile yapılan bu ortaklık, planlandığı gibi tam iki yıl sürer. Bu ortaklık sonunda 2012 yılında, Turkuaz Yatak kurulur. Ancak Turkuaz Yatak, Gama Mobilya’yı satın alarak devam ettiği için girişimciye göre, Turkuaz Yatak’ın doğuşu 2009 yılı olarak da düşünülebilir.

İç piyasa hedefi olmaksızın direkt olarak ihracat hedefiyle yola çıkan Turkuaz Yatak'ın, ilk pazarı Almanya olur. Ailenin önceki işletmecilik faaliyetlerinden süregelen tek müşterileri ile yola çıkılır. Turkuaz'ın ilk müşterisi olan Almanya'daki bu işletme (Tn), yaşanılan yangın felaketinden sonra kendilerini bırakmayan tek müşterileridir. Hatta işletme sahibi Bay Fiedal, o dönem kendilerine karşılıksız makine bile gönderecek kadar vefalıdır. Yangın sonrasındaki zor günlerinde Bay Fiedal'dan aldıkları bu desteği Alper Bey: "o zaman nasıl bir ilaçtı biliyor musunuz, baba oğluna ancak yapar böyle bir şeyi” "sözleriyle ifade etmektedir. Bu işletme ile kurulu güçlü ilişkiler, bugün hala devam etmektedir.

Almanya ile başlayan ilk faaliyetler, ailenin eski ağ ilişkilerinin canlandırılması ile devam eder. Girişimci, kökeni babasına ve amcasına, hatta daha da öncelere dedesine kadar dayanan bu ağ ilişkilerini, şu sözleriyle açıklamaktadır:

"Orada bizim akraba gibi sevdiğimiz, yakın olduğumuz insanlar vardı. Onlara gittim. Bu ilişkilerin kaynă̆ hep iş tabi. Kaynağı için aslında dedeme bakmak lazım. Dedem Mercedes 'te çalışmaya gitmiş. Amcamın biri orada kalmış, babam orada okumuş 4 -5 sene. Buraya gelmiş tekrar oraya gitmiş derken, orada da bir çevremiz olmuş. Ondan sonra babam orada Türk-Islam Birliği Başkanlı̆̆ yaptı bir dört sene kadar. Amcam yine aktifti. Almanya Mannheim'da Almanya'nın ilk minareli camisini yaptırdılar. Bunlar sayesinde orada bir Türk çevresi oluştu. Sonradan babam Türklerle çalışmaya başlamış, orada exportçulukyapmış. Bundan dolayı exportçuların tamamını tanıyoruz. Biliyorum hepsini, çünkü çocukluğum onlarla geçti."

Turkuaz'ın kuruluş ve gelişim sürecinde genç girişimci, bu eski ilişkileri canlandırıp var olan ilişkileri de koruma yoluna gider. Özellikle babasının bu süreçteki rolü büyük olur. Babasının eski müşterileri, artık kendilerini unutmuş üretim yaptıklarını bile bilmiyorlarken, bu işletmelerle tekrar temasa geçilir. Eski müşteriler yanında Almanya pazarında girişimci, hem 
babası aracılığıyla sahip olduğu sosyal çevreyi, hem de orada yaşayan başta amcası (Ta) olmak üzere diğer akrabalarının sosyal ilişkilerini kullanır. İlk üç yıl pazar araştırması ve işletmenin tanıtımıyla geçer. Bu yoğun sürecin geri dönüşleri de güzel olur. Bu süreçte işletme, fuarlar aracılığıyla on yeni işletme ile (T1, T2, T3, T4, T5, T6, T7, T8, T9 ve T10) bağlantı sağlayarak çalışmaya başlar. İlk yıl yani 2012'de, Turkuaz 1.750.000 EUR ihracat ile başlamış, 2015'e gelindiğinde ise ihracatı 4.500.000 EUR olmuştur. O dönemki yoğun çabaları, Alper Bey’in şu sözlerinden daha iyi anlaşılmaktadır:

\begin{abstract}
"Bu ilişkilerimizi biz canlandırdık ve var olan ilişkilerimizi koruma yoluna gittik. Oradaki (Almanya) sosyal çevremizi kullandık. Akrabalarımızın sosyal çevresini kullandık. Ortamlarda oturduk, konuştuk, fuarlardan edindiğimiz firmalardan çalışılacak, çalışılmayacakları belirledik. Belirlediklerimizin tabiri caizse kapılarında yattı. Babam, ben, Hilal Hanım randevu kopardık, numuneler yaptı, kargolar, numuneler gönderdik. Ama bize dönüşleri güzel oldu. Illk 3 yıl zaten böyle geçti."
\end{abstract}

Turkuaz'ın ihracat faaliyetleri, başka pazarların da eklenmesiyle artarak devam eder. Bu artışta, işletmenin ürün kalitesini ortaya koymasının yanında, yine ağ ilişkilerinin önemli rol oynadığı görülmektedir. Girişimci bu durumu şöyle anlatmaktadır:

“Avrupa'daki büyük firmalar kendi aralarında konuşuyor zaten. Sen nereden allyorsun, sen nereden allyorsun diye. Kalitemizi ortaya koyunca diğerleri de bu sayede bizi buldu. Tabi eski müşterilerimiz de bizi buldu."

Polonya ve Macaristan'dan Beta Grup kaynaklı eski müşterileri (Tx ve Ty) kendilerini bularak, Turkuaz'ın müşteri portföyüne eklenirler. Babalarının Hollanda'da eskiden ürün verdiği iki müşterisi (Td ve Te) ile tekrar kurulan temaslar da, Turkuaz Yatak'ın Hollanda pazarına girişini sağlar. Diğer taraftan eski müşterileri Jucky Arraut (Tj), işletmenin Belçika ve Hollanda pazarlarına girişinde ve bu pazarların gelişiminde etkili olur. Tabi özellikle Hollanda pazarında eski ilişkilerin canlandırılmasının hiç kolay olmadığı, Alper Bey’in şu ifadelerinden anlaşılmaktadır:

“Oradaki ana 1-2 firmaya (Hollanda'da) bizim eskiden mal vermişliğimiz vardı. Bu işin lokomotifi Almanya gibi görünür ama Hollanda'dır aslinda trendi belirleyen. Biz onlara tekrar gittik. Bu defa onlar bizi gördüler. Kayserili mantı̆̆gyla dedik ki, biz buradan nereye gidebiliriz? Buraya gidebiliriz, şuraya gidebiliriz. Ondan sonra biz o kapılarda yattık. Kapıların önünde yattı yani. Bir kere olmadı, bir daha olmadl, yine olmadl, derken ..."

2014 yılına kadar Alper Bey ve kardeşi Turkuaz'1 birlikte devam ettirerek, güzel bir ivme yakalarlar. $\mathrm{Bu}$ süreçte işletmenin başarısı Cumhurbaşkanı'ndan, Başbakan'dan ve KOSGEB'den alınan ödüller ile taçlandırılır.

Turkuaz Yatak’ın gelişim ve eş zamanlı olarak uluslararasılaşma sürecinde Eximbank, KOSGEB ve İhracatçılar Birliği'nden de önemli destekler sağlanır. Eximbank’tan sağlanan ihracat taahhütlü kredi ile fabrika arsası ve binası satın alınır. KOSGEB'den makine desteği alınır. İhracatçılar Birliği’nden fuar destekleri sağlanır. Bu üç kurumu etkin kullandıklarını 
belirten Alper Bey, aile ve arkadaşlarından da kritik destekler sağlar. Babasının yukarıda belirtilen katkıları dışında, kardeşi hem işlerin yürütümüyle birebir ilgilenir, hem de girişimciye yoğun bir duygusal destek sağlar. Alper Bey'in Hollanda'daki yakın arkadaşı Şahin Bey (Tş) ise, teknik konularda ve oradaki müşterilerle ilgili konularda önemli destekler verir. Ayrıca bir mühendis olmasından kaynaklanan mühendis çevresinin de başarısında etkili olduğunu belirten girişimci, bu etkiyi şu sözleriyle ifade etmektedir:

\begin{abstract}
“Arkadaşlarımı şurada çok kullandım ben; makine alımlarında, programlarda, dizaynlarda ve bunların kurulumunda. Tabiri caizse para ödemedim ya da bir makine alacağım içeriye, hemen diyorum ya oğlum bunu nasıl yapacă̆ız. Başkasının 50.000-60.000 Euro'ya yapacă̆ şeyi ben 30.000-35.000 Euro'ya hallettim. Mesela şuradaki ralli car'ın tasarımı tamamen bana ait. Kalıplarını üniversiteden yakın bir arkadaşıma (Tk) yaptırdım. Onun kalıbını yaptırmaya dışarıda 60.000-70.000 TL'ler isterler. 10.000 TL'ye yaptırdım, bir de yemeğe mal oldu bana. Üretimde çok iyi oluyor. Mesela bir dizaynı yapamıyorum ya da yurt dışından geliyor, ben 1 saat sonra yapıp gönderebiliyorum. Başka bir firmanın 2-3 gününü alır yani. Ya da gitti geldisi olur. Yine üniversiteden başka bir yakın arkadaşım (Tt), ürün ăgaçlarının yapılmasında ve erp programinda çok destek oldu."
\end{abstract}

Bu başarılı gidiş, 2014 yılında yaşanan başka bir talihsiz olayla sekteye uğrar. Alper Bey'in geçirdiği trafik kazası ve sonrasında yaşadığı zorlu dönem, tüm enerjisini alır. Yabancıların işlerinde katı olması da eklendiğinde bu süreç, işletme için de zor günleri beraberinde getirir. Sürece tanıklık eden, ailenin eski iş ilişkilerinden kaynaklı bir tanışıklığa sahip oldukları Ayaz Holding'in sahibi Cem Bey, "sizin pazarınız var, bu pazarı birlikte büyütebilir miyiz?” diyerek Alper Bey’e ortaklık teklif eder. Alper Bey o günlerde eski günlerin performansına hala ulaşamadıkları düşüncesindedir. Durumu kendi sözleriyle şöyle ifade etmektedir: "Hala İkea ile çalışamıyoruz. Kapasitem yetmiyor. Yurt dışında depo lazım. Bunları sağlarsam yıllık 4,5 milyonluk ciroyu ikiye katlarım diye düşündüm”. Bu doğrultuda Cem Bey (Tc) ile 2015 yılında Gecce adı altında yeni bir işletme kurulmasıyla başlayan ortaklık, iki buçuk-üç yıl kadar sürer. Alper Bey’in işletmesinin yaşadığı finansman sıkıntısı nedeniyle zorunlu olarak yaptığı ilk ortaklığın aksine, bu defaki zorunlu bir ortaklık değildir. $\mathrm{Bu}$ ortaklığın amacı, işletmenin pazar payını büyütebilmek için gerekli gördüğü yatırımları yapmasına imkân sağlayabilecek ek kaynaklara ulaşmaktır. Ancak pastadan aldıkları payın birken üç olmadığını görerek, ortaklıktan ayrılma kararı alırlar. Ortaklığın bitişi 2018 yılının ikinci yarısında gerçekleşir.

Turkuaz Yatak ayrıca iki üründe (arabalı yatak), Avrupa'da çok büyük bir işletme ile işbirliği geliştirir. Ürün tasarımlarının tamamını bu işletmenin fikirleri doğrultusunda Türkiye'de kendileri yapar. Geliştirilen tasarımlar ise Almanya merkezli bu işletmeye (Ti) satılır. Aralarında yapılan sözleşme gereği Turkuaz, geliştirilen dizaynları üçüncü kuruluşlar ile paylaşmayacak ve satışlar üzerinden yüzde 3 oranında işletmeler birbirlerine komisyon ödeyecektir. Başarılı bir şekilde devam eden bu işbirliğinin gelişimine baktığımızda, temelinin 
yine bir ağ ilişkisine dayandığı görülmektedir. Üretici ararken Almanya’da sektördeki çeşitli işletmelerle görüşen işletme, Turkuaz Yatak'ın yatak müşterisi olan bir işletmeye (Tm) 'biz Türkiye'de kime güvenebiliriz" der ve bu işletmenin yönlendirmesi neticesinde kendilerine ulaşır.

Turkuaz Yatak'ın başarısında fuarlar da etkili olur. Alper Bey, fuarların güven tazelenmesi yoluyla eski ilişkilerin canlandırılması ve mevcut ilişkilerin geliştirilmesinde kendileri için oynadığı önemli rolü, şu sözleriyle ifade etmektedir:

“Fuarlar çok önemli. Fuarda bizi gördükleri zaman, müşterilerimiz çok memnun oluyorlar. Kendi yerleri gibi girip çıkıyorlar. Yeni ürünleri konuşuyoruz, yeni dizaynlarımızı götürüyoruz. Ya da eski bağlantılarımızı yeniliyoruz, güven tazeliyoruz. Bizi görmek çok hoşlarına gidiyor. Fuarlarda hiçbir şey satmasanı bile, bizim gibi firmaların katılması gerekiyor. Bizi orada gördüklerinde, 18 yıllık bir firmayı görmüş gibi oluyorlar."

İşletmenin Almanya'da ve Belçika'da birer acentesi de bulunmaktadır. Belçika'daki acentesi (A1); Fransa, Belçika, Hollanda'daki müşterilere bakarken, Almanya'daki acentesi (A2); Polonya, Macaristan, Avusturya ve Almanya'daki müşterilerle ilgilenmektedir. Dolaylı olarak işletmeyi temsil eden bu acenteler, müşterilerle ilişkilerin sağlıklı bir biçimde sürdürülmesi başta olmak üzere, işletmeye çeşitli avantajlar sağlarlar. Bu avantajlar, Alper Bey tarafından şöyle ifade edilmektedir:

\begin{abstract}
"Benim birebir diyalogda olduğum müşteriyi de acenteye veriyorum. Acentenin 2 firması var sadece. Ben niye acenteye para ödüyorum? Çünkü bir sorun olduğu zaman onu bulun diyorum. Benim her dakika oraya gitmem mümkün değil. Her şeyde devreye giriyor. \% 2 veriyorum ama bu sizin \% 2 ile yapacağınız şey değil. Tak telefon ediyorum, devreye giriyor. Numuneyi al okeylettir diyorum, gümrükte çıkan sorunları çözüyor, fuarda bizi pazarlıyor. Verdiğim parayla yaptıramayacağım işleri yapıyor benim için."
\end{abstract}

Yukarıda yer verilen kuruluş ve gelişim hikayesinden anlaşı1dığı üzere başarı1l, genç ve girişimci bir işletme olarak sektöründe fark yaratan Turkuaz Yatak, küresel doğan işletmelerin tipik bir örneğini yansıtmaktadır.

\title{
6. BULGULARIN DEĞERLENDİILILESI
}

Ulaşılan bulgulardan hareketle Turkuaz'ın kuruluşuyla birlikte eş zamanlı olarak uluslararasılaşma başarısı göstermesinde, ağ ilişkilerinin güçlü biçimde etkili olduğu anlaşılmaktadır. Bu süreçte ağ ilişkilerinin rolü, araştırma verilerine yapılan içerik analizi ile yedi tema altında toplanmıştır. Bu temalar; pazar bilgisi ve pazar firsatları, finansal kaynak, fiziksel kaynak, operasyonel destek, önemli aktörlere erişim, manevi destek ve güvendir. İşletmenin uluslararasılaşmasında etkili olduğu tespit edilen ağ ilişkileri, aşağıda Şekil 2.’de ağ haritası yardımıyla gösterilmektedir. 


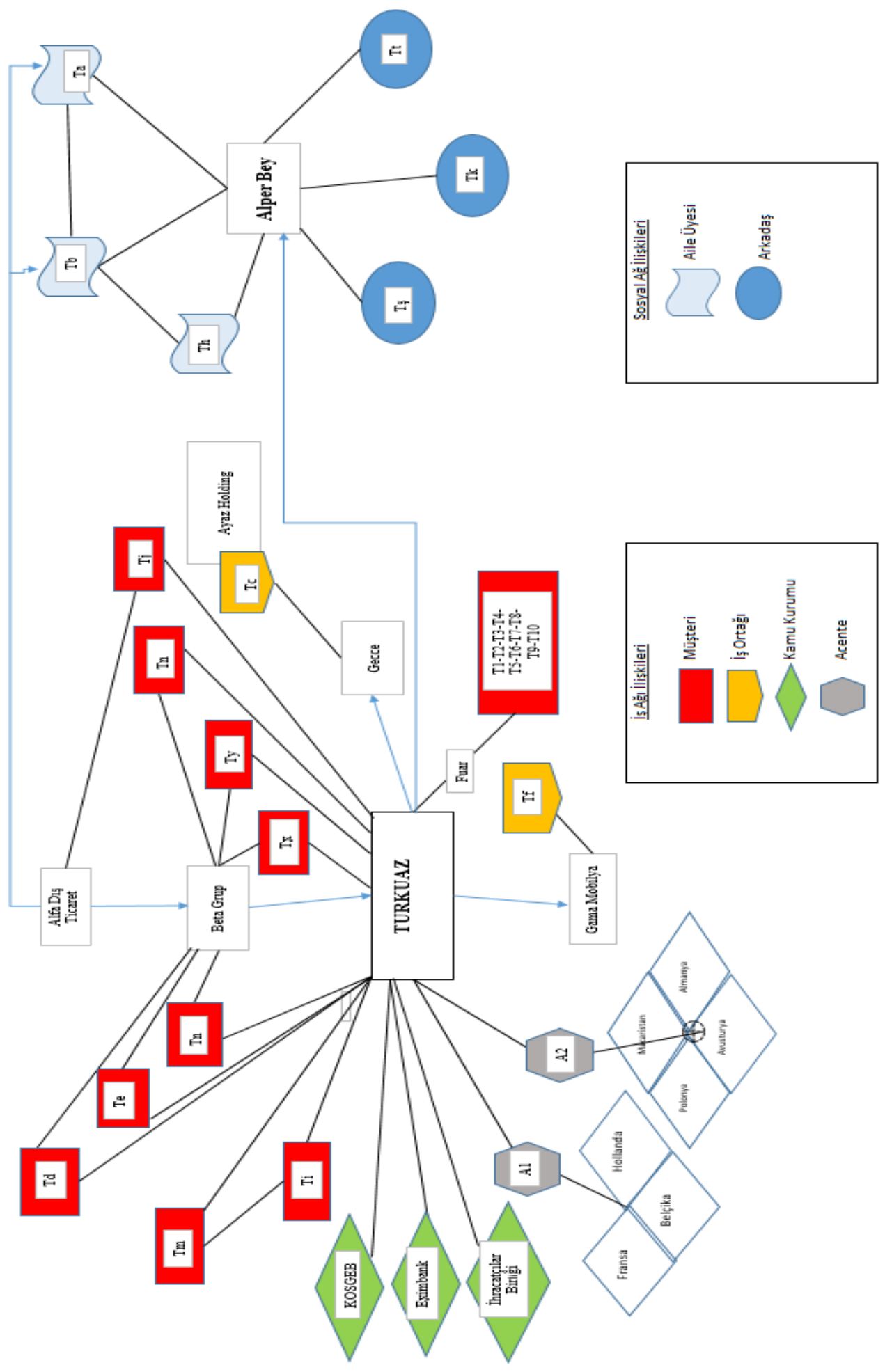

Şekil 2. Turkuaz Yatak'ın Ağ Haritası

Tanımlanan her bir ağ ilişkisinin sosyal ve iş ilişkisi temelinde sınıflandırılmasında, literatür incelemesinde yer verilen temel noktalardan hareket edilerek girişimcinin ailesi, arkadaşları ve meslektaşları ile sosyal temelde kurduğu ilişkiler, "sosyal ağ ilişkisi”" olarak kabul edilmiştir. İşletmenin müşterileri, dağıtıcıları, rakipleri, tedarikçileri ve devlet kurumları 
gibi çeşitli aktörlerle geliştirdiği ilişkiler ise iş ağı ilişkisi olarak dikkate alınmıştır. $\mathrm{Bu}$ doğrultuda örnek olay işletmesinde tespit edilen ağ ilişkileri ve bu ilişkilerin sosyal ve iş temelli olarak sınıflandırılmasına, aşağıda Tablo 2.'de yer verilmektedir.

Tablo 2. Turkuaz Yatak’ın A ̆ İlişkileri Sınıflandırması

\begin{tabular}{|c|c|}
\hline Sosyal Ağ İlișkileri & İș Ağı İlișkileri \\
\hline $\mathrm{Tb}$ (baba) & Tn (eski müşteri) \\
\hline Hilal Hanım (Th) (kardeş) & Tf (sosyal temelde başlayıp iş ortakllğına dönüş̧en tanışiklik) \\
\hline $\mathrm{Ta}(\mathrm{amca})$ & T1 (fuar arachliğyyla edinilen müşsteri) \\
\hline 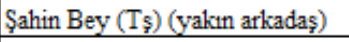 & T2 (fuar arachliğyyla edinilen müşsteri) \\
\hline $\mathrm{Tk}$ (üniversiteden yakın arkadaş) & T3 (fuar aracliğı̆yla edinilen müșteri) \\
\hline \multirow[t]{20}{*}{$\mathrm{Tt}$ (üniversiteden yakın arkadaş) } & T4 (fuar arachliğıyla edinilen müşsteri) \\
\hline & T5 (fuar arachliğıyla edinilen müş̧teri) \\
\hline & T6 (Fuar aracilığıyla edinilen müșteri) \\
\hline & T7 (fuar arachliğyyla edinilen müşsteri) \\
\hline & T8 (fuar aracliğy̆yla edinilen müşteri) \\
\hline & T9 (fuar arachliğıyla edinilen müşteri) \\
\hline & T10 (fuar aracilığyla edinilen müșteri) \\
\hline & $\mathrm{Tx}$ (eski müşteri) \\
\hline & Ty (eski müşteri) \\
\hline & $\mathrm{Td}$ (eski müşteri) \\
\hline & $\mathrm{Te}$ (eski müşteri) \\
\hline & $\mathrm{Tj}$ (eski müşsteri) \\
\hline & Eximbank \\
\hline & KOSGEB \\
\hline & İhracatçlar Birliği \\
\hline & Cem Bey $(\mathrm{Tc})$ (eski iş iliş̧kileri kaynakhı tanıdık) \\
\hline & $\mathrm{Ti}$ (stratejik işbirliği geliştirilen işletme) \\
\hline & $\operatorname{Tm}$ (mevcut müșteri) \\
\hline & A1 (acente) \\
\hline & A.2 (acente) \\
\hline
\end{tabular}

Turkuaz Yatak'ın ağ ilişkileri değerlendirildiğinde; tespit edilen toplam 31 ağ ilişkisinin 25'inin (\% 81) iş ağı ilişkisinden, 6`sının (\% 19) ise sosyal ağ ilişkisinden oluştuğu görülmektedir. Sosyal ve iş ağı ilişkilerinin dağılımı, oluşturulan bir grafik yardımıyla aşağıda Şekil 3.' de gösterilmektedir. Nihai olarak işletmenin ağında, iş ilişkileri ağırlıklı bir yapı olduğu görülmektedir.

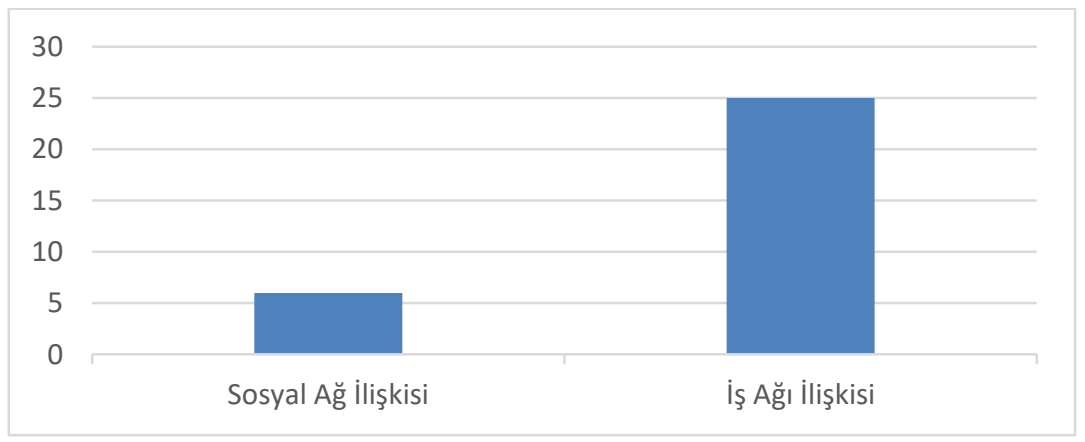

Şekil 3. Turkuaz Yatak’’n A ̆̆ İlişkilerinin Dağılımı 
Oviatt ve McDougall (1994), güçlü uluslararası iş ağ1 ilişkilerini başarılı uluslararası yeni girişimlerin en önemli özelliğinden biri olarak görmektedirler. Benzer şekilde Chetty ve Wilson (2003), hızlı uluslararasılaşmanın iş ağlarına erken odaklanmayla mümkün olduğu bulgusunu sunmaktadırlar. Coviello ve Munro (1995) ise, küresel doğan işletmelerde uluslararasılaşmanın ilk aşamalarında, iş ağlarının özellikle önemli olduğunu göstermişlerdir. Araştırmamızda incelen örnek olay işletmesinde yoğunlukla tespit edilen iş ağı ilişkilerinin bu bulgularla paralel olarak, işletmenin kuruluşuyla birlikte uluslararasılaşmasında güçlü biçimde etkili olduğu görülmüştür. Chetty ve Campbell-Hunt (2004)'1n araştırmalarında gösterdikleri gibi, Turkuaz Yatak'ın sahip olduğu iş ağları yeni firsatlar, pazar bilgisi ve enformasyon sağlayarak, işletmenin aşamalı olarak değil, kuruluşuyla birlikte hızla uluslararasılaşmasına olanak tanımıştır. Özellikle ailenin geçmiş sektör tecrübesinden kaynaklı eski müşterilerinin, bu süreçteki önemli rolleri dikkat çekicidir. Turkuaz'ın ilk müşterisi olan Almanya'daki (Tn), Beta Grup zamanından süregelen ve yangın felaketi sonrasında kendilerini bırakmamış tek müşterileridir. Benzer şekilde Polonya ve Macaristan'dan Beta Grup kaynaklı eski müşteriler (Tx ve Ty) ve Hollanda'da eskiden ürün verilen firmalar (Td ve Te) ile tekrar iletişime geçilmesi, Turkuaz'ın bu pazarlarda uluslararası genişlemesine yönelik yeni firsatlar elde etmesini sağlamıştır. Almanya merkezli büyük bir işletmeyle stratejik işbirliği geliştirilmesinde de, aynı pazarda ürün verilen mevcut yatak müşterisi (Tm) aracılık etmiştir. Bu detaylar iş ağı ilişkilerinin, uluslararasılaşmaya yönelik olarak önemli aktörlere erişim sağlanmasını kolaylaştırma rolünü ön plana çıkarmaktadır. Ayrıca Turkuaz ile Alman işletme arasında geliştirilen stratejik işbirliği Chetty ve Campbell-Hunt (2004)'1n, potansiyel uluslararası ortakları tanımlamak ve müteakip işbirliklerinden fayda sağlamak için iş ağı ortaklarının önemli kolaylaştırıcı aktörler olduğu görüşlerini doğrulamaktadır.

Karra ve Philips (2004), ağların genellikle belirsiz ortamlarda yüksek derecede güven sağlayan, etnik veya diğer sosyal bağlar üzerine kurulu olduğunu ve sosyal destek sağlamanın yanında, aynı zamanda iletişim ve değişim kanalları olarak da işletildiklerini vurgulamaktadırlar. Araştırmacılara göre bu bağlar, diğer aktörlerle iletişim kurma şansını ağ dışındakiler için elde edilmesi mümkün olmayan bir dereceye kadar artırırlar. Nitekim Turkuaz'ın uluslararasılaşmasının başlangıcında bir taraftan girişimcinin ailesinden aldığı sosyal destek etkili olurken, diğer taraftan babası ve amcasının Almanya'da sahip oldukları sosyal çevre, girişimcinin önemli aktörlere erişim sağlayabilmesini ve dışarıdan elde edilmesi pek mümkün olmayan değerli pazar bilgileri elde edebilmesini sağlamıştır. Bu sosyal ağlar sayesinde fuarlar aracılığıyla tespit edilen potansiyel müşteriler arasından, çalışılacak ve 
çalışılamayacaklar belirlenmiş ve hedeflenen müşterilere ulaşılmıştır. Bu yöntemle işletme, müşteri portföyüne on yeni müşteri (T1, T2, T3, T4, T5, T6, T7, T8, T9 ve T10) eklemiştir.

Örnek olay işletmesinden elde edilen bulgular, Riddle ve Gillespie (2003)’nin, tekstil sektöründe faaliyet gösteren Türk işletmeleri ile gerçekleştirdikleri araştırmalarının sonuçlarıyla da benzerlik göstermektedir. Riddle ve Gillespie (2003), arkadaşlık ve aile bağları gibi gayri resmi sosyal bağların, yeni kurulan firma sahipleri için kritik bilgi kaynakları olduğunu ortaya çıkarmışlardır. Bu sosyal bağların yeni girişimci Türk firma sahipleri nezdinde -tıpkı Turkuaz Yatak’ın girişimcisi Alper Bey'in arkadaşlarından aldığı program kurulumu, dizayn oluşturma destekleri, ailesinden ve Almanya'daki sosyal ağ ilişkilerinden pazar bilgisi edinmesinde olduğu gibi- teknolojik gelişmeler ve tedarikçiler hakkında bilgi elde edilmesinde önemli rol oynadığı bulunmuştur (Riddle \& Gillespie, 2003). Bu doğrultuda sosyal ağ ilişkilerinin, hem Turkuaz'ın uluslararasılaşmasının başlangıcında hem de sonrasındaki uluslararası gelişiminde, önceki çalışmalarda (Chetty \& Blankenburg Holm, 2000; Coviello \& Munro, 1995; Ellis \& Pecotich, 2001; Harris \& Wheeler, 2005; Kontinen \& Ojala, 2011; Madsen \& Servais, 1997; Özgen \& Baron, 2007; Mort \& Weerawardena, 2006; Vasilchenko \& Morrish, 2011 Prashantham \& Dhanaraj, 2010; Riddle \& Gillespie, 2003) belirtildiği gibi yeni pazar firsatlarının tanımlanması ve pazar bilgisi oluşturulmasında etkili olduğu görülmüştür. Ayrıca bulgularımız erken ve hızlı uluslararasılaşan işletmelerin bu başarısının, kuruluş öncesinde girişimcileri tarafından oluşturulmuş güçlü bilgi temelli sosyal ağ ilişkilerine dayandığını (Masango \& Marinova, 2014) ispatlamakta ve erken uluslararasılaşmada sosyal ağ ilişkilerini kritik öneme sahip gören çeşitli araştırmacıların (Zain \& Ng, 2006; Andersen, 2006; Ellis, 2000; Harris \& Wheeler, 2005; Komulainen, Mainela, \& Tähtinen, 2006; Zhou, Wu, \& Luo, 2007; Manolova vd., 2010; Vasilchenko \& Morrish, 2011) görüşlerini desteklemektedir.

Diğer yandan Chetty ve Wilson (2003); Gulati ve Gargiulo (1999); Hoang ve Antoncic (2003); Nummela, (2002) ve Tang (2011) gibi araştırmacılar tarafından vurgulandığ gibi, ağ ilişkilerinin Turkuaz'ın hem finansal hem de fiziksel çeşitli kaynaklara erişiminde önemli roller oynadığı tespit edilmiştir. Nitekim Turkuaz’ın kuruluşu, Gama Mobilya’yı satın almasıyla gerçekleşmiştir. Gama Mobilya ise aile çevresinden eski bir tanıdık (Tf) ile yapılan ortaklık ile kurulmuştur. Vasilchenko ve Morrish (2011)'in, erken aşamada sosyal ağların sonraki uluslararasılaşma sürecinde etkili olan iş ağlarına dönüştüğü tespiti ile uyumlu olarak, sosyal temelde başlayan bu ilişki, bir iş ilişkisine dönüşmüştür. Nihai durumda girişimci, bu kişiyi "finans ortağı” olarak tanımlamaktadır. 2015 yılında Ayaz Holding ile Gecce'nin kuruluşu yoluyla başka bir ortaklık daha yapılmış, bu ortaklık ile de işletmenin uluslararası 
genişlemesine yardımcı olacak ek finansal kaynă̆ın temini amaçlanmıştır. Ayrıca Eximbank’tan sağlanan ihracat taahhütlü kredi ile Turkuaz'ın faaliyet gösterdiği fabrika arsa ve binasının mülkiyeti elde edilmiştir. Bu finansal kaynakların yanında işletme, ağ ilişkileri yoluyla çeşitli fiziksel kaynaklara da ulaşmıştır. Beta Grup kaynaklı eski müşterileri (Tm) tarafından bedelsiz gönderilen makine ve KOSGEB'den sağlanan makine desteğinin yanı sıra girişimci, yakın arkadaşlarından ürün dizaynlarının ve kalıplarının yapımı gibi fiziksel kaynaklar sağlamıştır. Bu kaynaklara ek olarak, işletmenin ağ ilişkilerinden faaliyetleri için önemli operasyonel destekler sağladığı da anlaşılmaktadır. İş ağı ilişkisi olarak nitelenen Almanya ve Belçika'daki acentelerinin sağladıkları operasyonel destek, girişimci tarafından "verdiğim parayla yaptıramayacă̆ım işleri yapıyorlar benim için" sözleriyle ifade edilmektedir.

Uluslararasılaşmanın ilk aşamalarında sosyal ağ ilişkilerinin sağladı̆̆ı "manevi destek" ve "güven", görüşme verileri üzerinde yapılan içerik analizinde ortaya çıkan diğer temalar olmuştur. Vasilchenko ve Morrish (2011) tarafından Yeni Zelandalı işletmeler üzerinde tespit edildiği gibi, Turkuaz' da uluslararasılaşmanın erken aşamalarında sosyal ağ ilişkilerinin sağladığı manevi destek ve güven, fırsatların keşfedilmesi ve kullanılmasına imkân tanıyarak, işletmenin hızlı uluslararasılaşmasında etkili olmuştur. Girişimci, işletmesinin kuruluş ve eş zamanlı gerçekleşen uluslararasılaşma sürecinde özellikle babası ve kardeşinden aldığı yoğun duygusal desteği sıklıkla vurgulamaktadır. Aile desteğinin yanı sıra yakın arkadaşlarından (Tş, Tt, Tk) ve Almanya'daki sosyal çevresinden de bu süreçte çeşitli manevi destekler sağladığı anlaşılmaktadır. Ayrıca fuarların güven sağlama ve güven tazeleme fonksiyonuyla işletmenin gelişimindeki önemli rolleri, girişimcinin bu organizasyonlara yönelik "eski bağlantılarımızı yeniliyoruz, güven tazeliyoruz" sözlerinden anlaşılmaktadır.

Tüm bulgular birlikte değerlendirildiğinde, her iki ağ türünün de küresel doğan işletmelerin uluslararasılaşmasını olumlu yönde etkilediği görüşünü savunan Eberhard ve Craig (2013), Melen ve Nordman (2007), Rialp, Rialp ve Knight (2005) gibi araştırmacıların görüşleri paralelinde, Turkuaz'ın erken uluslararasılaşma başarısında hem sosyal hem de iş ağı ilişkilerinin önemli roller oynadığı sonucuna ulaşılmaktadır. Ancak Ibeh ve Kasem (2011)'in, sosyal ağların uluslararasılaşmanın başlangıç aşamasında daha etkili olduğu, iş ağlarının ise sonraki aşamalarda baskın hale geldiği bulgusu, araştırmamız tarafından doğrulanmamıştır. Çünkü yukarıda anlatıldığı gibi, Turkuaz'ın kuruluşu ve eş zamanlı olarak uluslararasılaşmasında, sosyal ağ ilişkileri yanında iş ağı ilişkilerinin önemli roller oynadığı 
tespit edilmiştir. Nihai olarak elde edilen bu faydaların, işletmenin erken uluslararasılaşmasında “daha önemlilik" doğrultusunda kolayca kategorize edilemeyeceği anlaşılmıştır.

\section{SONUÇ VE ÖNERILLER}

Çalışmamızda Türkiye'de küresel doğan bir işletme örneği üzerinden, ağ ilişkilerinin erken uluslararasılaşmadaki rolü araştırılmıştır. Bu kapsamda, 2015 yılı KOSGEB KOBİ ve Girişimcilik Ödülleri Yarışması'nda “Küresel Doğan Girişimci” kategorisi finalisti, Bursa ilinde faaliyet gösteren Turkuaz Yatak'ın, kuruluş ve eş zamanlı olarak gerçekleşen uluslararasılaşma süreci ele alınmıştır. Araştırmada bu süreçte etkili olan ağ ilişkileri tespit edilerek, sosyal ve iş ağı ilişkisi temelinde sınıflandırılmış ve bu ilişkilerin erken uluslararasılaşmaya yönelik sağladıkları belirlenmeye çalışılmıştır. Veri toplamada temel kaynak olarak yüz yüze görüşme yönteminin kullanıldığı örnek olay çalışmasından elde edilen bulgular, işletmenin erken uluslararasılaşmasında ă̆ ilişkilerinin önemli bir kolaylaştırıcı olduğunu gözler önüne sermektedir. Bunun yanında çeşitli ülkeler nezdinde yürütülmüş, küresel doğanların ağ ilişkilerini konu edinen araştırma bulgularının da, ülkemiz özelinde büyük ölçüde geçerli olduğu sonucu ortaya çıkmıştır.

Uluslararasılaşmanın başlangıcında, özellikle girişimcinin önceki ağ ilişkilerinin etkili olduğu görülmüştür. Diğer yandan ağ ilişkilerinin, baskın olarak iş ağı ilişkilerinden oluştuğu tespit edilmiştir. Almanya' da büyük bir işletme ile stratejik işbirliği geliştirilmesinde de mevcut bir iş ağ1 ilişkisi aracılık etmiştir. Ancak buradan hareketle işletmenin erken uluslararasılaşmasında, iş ağı ilişkilerinin sosyal ağ ilişkilerinden daha önemli bir rol oynadığ1 gibi bir genelleme yapmak mümkün değildir. Çünkü bu süreçte hem sosyal hem de iş ağ1 ilişkilerinden, daha önemlilik doğrultusunda kolayca kategorize edilemeyecek önemli faydalar sağlandığı anlaşılmıştır. Nihai olarak Eberhard ve Craig (2013) ve Melen ve Nordman (2007), Rialp, Rialp ve Knight (2005) gibi araştırmacılar tarafından da belirtildiği gibi, hem sosyal hem de iş ağı ilişkilerinden oluşan bir bileşimin, erken uluslararasılaşmada faydalı olduğu sonucuna ulaşılmıştır. Turkuaz'ın erken uluslararasılaşmasında ağ ilişkilerinin rolü, araştırma verilerine yapılan içerik analizi ile yedi tema altında toplanmıştır. Bu temalar; pazar bilgisi ve pazar firsatları, finansal kaynak, fiziksel kaynak, operasyonel destek, önemli aktörlere erişim, manevi destek ve güven olarak ortaya çıkmıştır.

Araştırma tek bir işletme üzerinden yürütülmüş olsa da, başarısı tescilli küresel doğan bir işletme üzerinde gerçekleştirilmesi ve ağ ilişkilerinin erken uluslararasılaşmadaki itici gücünü ilgili literatür çerçevesinde ortaya koyması nedeniyle, alan yazınımıza katkı sağlayacağı 
düşünülmektedir. Doğuştan küresel bir işletme yaratmak isteyen girişimciler için cesaretlendirici bir örnek teşkil etmesi nedeniyle de değerlidir. Ancak nitel araştırmalardan elde edilen bulguların genellenebilmesi güç olduğundan, ulaşılan sonuçların Türkiye'deki tüm küresel doğan işletmelere genellenebilmesi söz konusu değildir. Bu doğrultuda gelecekte yapılacak çalışmalarda araştırmacılara, daha büyük örneklemler üzerinde çalışılması önerilebilir. Küresel doğan işletmelerin, giderek daha fazla birbirine entegre haline gelen dünya ekonomilerinde, gelecekte sayıca daha da artması kaçınılmaz görülmektedir. Bu sebeple bu işletmelerin erken uluslararasılaşmasını açıklamada önemli bir bakış açısı olarak görülen ağ ilişkileri perspektifinden, Türkiye nezdinde farklı yöntemlerle gerçekleştirilecek daha fazla araştırmaya ihtiyaç duyulmaktadır. 


\section{KAYNAKÇA}

Agndal, H. ve Chetty, S. (2007). "The İmpact Of Relationships On Changes In Internationalisation Strategies Of Smes". European Journal of Marketing, 41(11/12), 1449-1474. https://doi.org/10.1108/03090560710821251

Akhter, M. (2013). Origin And Role Of Social Networks : A Comparative Study Of Born Global Firms Of France And Pakistan. Ph.D. Thesis. BEM Management School, France.

Andersen, O. (1993). "On the Internationalization Process of Firms: A Critical Analysis". Journal of International Business Studies, 24, 209-231. https://doi.org/10.1057/palgrave.jibs.8490230

Andersen, P. H. (2006). "Listening To The Global Grapevine: SME Export Managers' Personal Contacts As A Vehicle For Export Information Generation". Journal of World Business, 41(1), 81-96. https://doi.org/10.1016/j.jwb.2005.10.006

Anderson, J. C., Hakansson, H. ve Johanson, J. (1994). "Dyadic Business Relationships Within A Business Network Context". Journal of Marketing, 58(4), 1. https://doi.org/10.2307/1251912

Andersson, S. ve Wictor, I. (2003). "Innovative Internationalisation In New Firms : Born Globals - The Swedish Case". Journal of International Entrepreneurship, 1, 249-276. https://doi.org/10.1023/A:1024110806241

Atlı, H. ve Kartal, B. (2014). "Küresel Doğan İşletmelerde Girişimcinin Bireysel Özelliklerinin Erken Uluslararasılaşmadaki Rolü". Dumlupınar Üniversitesi Sosyal Bilimler Dergisi, 39(1), 145-158.

Baskici, C. ve Ercil, Y. (2018). Uluslararasılaşma Sürecinin Başlamasında “Ă̆ Oluşturma Mekanizmaları". Business and Economics Research Journal, 9(4), 911-922. https://doi.org/10.20409/berj.2018.147

Bell, J. (1995). "The Internationalization Of Small Computer Software Firms A Further Challenge To "Stage" Theories". European Journal of Marketing, 29(8), 60-75. https://doi.org/10.1108/03090569510097556

Bembom, M. ve Schwens, C. (2018). "The Role Of Networks In Early İnternationalizing Firms: A Systematic Review And Future Research Agenda". European Management Journal, 36(6), 679-694. https://doi.org/10.1016/j.emj.2018.03.003

Berber, Ş., Köle, M., Taşçı, M. E., ve Can, E. (2018). "From Past To Present Born Global Phenomenon: A Thematic Analysis". Economics and Business Review, 4(18)(2), 80-97. https://doi.org/10.18559/ebr.2018.2.5

Bilkey, W. J. ve Tesar, G. (1977). "The Export Behavior Of Smaller-Sized Wisconsin Manufacturing Firms". Journal of International Business Studies, 8(1), 93-98. https://doi.org/10.1057/palgrave.jibs.8490783

Birley, S. (1985). "The Role Of Networks In The Entrepreneurial Process". Journal of Business Venturing, 1(1), $107-117$.

Brüderl, J. ve Preisendörfer, P. (1998). "Network Support And The Success Of Newly Founded Business". Small Business Economics, 10(3), 213-225. https://doi.org/10.1023/A:1007997102930 
Chetty, S. ve Campbell-Hunt, C. (2004). "A Strategic Approach To Internationalization: A Traditional Versus A "Born-Global" Approach". Journal of International Marketing, 12(1), 57-81. https://doi.org/10.1509/jimk.12.1.57.25651

Chetty, S. ve Holm Blankenburg, D. (2000). The Role of Business Networks in the Internationalisation of Manufacturing Firms : A Longitudinal Case Study. Içinde Advances in International Marketing, 4, $205-222$.

Chetty, S. K. ve Wilson, H. I. M. (2003). "Collaborating With Competitors To Acquire Resources". International Business Review, 12(1), 61-81. https://doi.org/10.1016/S0969-5931(02)00088-4

Coviello, N. E. (2006). "The Network Dynamics Of İnternational New Ventures". Journal of International Business Studies, 37(5), 713-731. https://doi.org/10.1057/palgrave.jibs.8400219

Coviello, N. E. ve Munro, H. J. (1995). " Growing The Entrepreneurial Firm Networking For International Market Development". European Journal of Marketing, 29(7), 49-61. https://doi.org/10.1108/03090569510095008

Coviello, N.E. ve McAuley, A. (1999). "Internationalisation And The Smaller Firm: A Review Of Contemporary Empirical Research". Management International Review, 39(3), 223-256. https://doi.org/10.2307/40835788

Coviello, N.E. ve Munro, H. (1997). "Network Relationships And The İnternationalisation Process Of Small Software Firms". International Business Review, 6(4), 361-386. https://doi.org/10.1016/S0969-5931(97)00010-3

Creswell, J. W. (2014). Research Design: Qalitative, Quantitative and Mixed Methods Approaches. Sage Publications (Fourth Edition).

Creswell, J. W. (2017). Nitel Araştırmacılar İçin 30 Temel Beceri. (Ç. D. H. Özcan, Ed.). Ankara: Anı Yayıncılık.

Czinkota, M. R. (1982). Export Development Strategies: US Promotion Policies. The International Executive. New York: Praeger. https://doi.org/10.1002/tie.5060070408

Çavuşgil, S. Tamer; Knight, G. ve Riesenberger, J. R. (2012). International Business: Strategy, Management And The New Realities (Second Edition). Pearson.

Çavuşgil, S.Tamer. (1980). "On The Internationalization Process Of Firm". European Research, 8(6), $273-281$. https://doi.org/10.1038/242427b0

Çavuşgil, S.Tamer, Knight, G. ve Üner, M. M. (2011). Türkiye’de Küresel Doğan İşletmeler. Ankara: Detay Yayınlar1.

Çavusgil, T. S. (1994). "A Quiet Revolution In Australian Exporters". Marketing News, 28(11), 18.

Dubini, P. ve Aldrich, H. (1991). "Personal And Extended Networks Are Central To The Entrepreneurial Process". Journal of Business Venturing, 6(5), 305-313. https://doi.org/10.1016/0883-9026(91)90021-5

Eberhard, M. ve Craig, J. (2013). "The Evolving Role Of Organisational And Personal Networks In International 
Market Venturing". Journal of World Business, 48(3), 385-397. https://doi.org/10.1016/j.jwb.2012.07.022

Ellis, P. D. (2000). "Social Ties And Foreign Market Entry". Journal of International Business Studies, 31(3), 443469.

Ellis, P. ve Pecotich, A. (2001). "Social Factors İnfluencing Export Initiation In Small And Medium-Sized Enterprises". Journal of Marketing Research, 38(1), 119-130. https://doi.org/10.1509/jmkr.38.1.119.18825

Fillis, I. (2001). "Small Firm Internationalisation: An Investigative Survey And Future Research Directions". Management Decision, 39(9), 767-783. https://doi.org/10.1108/00251740110408683

Fina, E. ve Rugman, A. M. (1996). "A Test Of Internalization Theory And Internationalization Theory: The Upjohn Company". MIR: Management International Review, 36(3), 199-213. https://doi.org/10.1097/00004583199405000-00013

Freeman, S. ve Cavusgil, S. T. (2007). "Toward A Typology Of Commitment States Among Managers Of BornGlobal Firms: A Study Of Accelerated Internationalization". Journal of International Marketing, 15(4), 1-40. https://doi.org/10.1509/jimk.15.4.1

Gabrielsson, M. ve Manek Kirpalani, V. H. (2004). "Born Globals: How To Reach New Business Space Rapidly". International Business Review, 13(5), 555-571. https://doi.org/10.1016/j.ibusrev.2004.03.005

Greve, A. (1995). "Networks And Entrepreneurship - An Analysis Of Social Relations, Occupational Background, And Use Of Contacts During The Establishment Process". Scandinavian Journal of Management, 11(1), 1-24. https://doi.org/10.1016/0956-5221(94)00026-E

Gulati, R. ve Gargiulo, M. (1999). "Where Do Interorhanizational Network Come From?", The American Journal of Sociology, 104(5), 1439-1493.

Harris, S. ve Wheeler, C. (2005). "Entrepreneurs' Relationships For Internationalization: Functions, Origins And Strategies". International Business Review, 14(2), 187-207. https://doi.org/10.1016/j.ibusrev.2004.04.008

Hoang, H. ve Antoncic, B. (2003). "Network-Based Research In Entrepreneurship". Journal of Business Venturing, 18(2), 165-187. https://doi.org/10.1016/S0883-9026(02)00081-2

Hordes, M. W., Clancy, J. A. ve Baddaley, J. (1995). "A Primer For Global Start-Ups". Academy of Management Perspectives, 9(2), 7-11. https://doi.org/10.5465/AME.1995.9506273262

Ibeh, K. ve Kasem, L. (2011). "The Network Perspective And The Internationalization Of Small And Medium Sized Software Firms From Syria". Industrial Marketing Management, 40(3), 358-367. https://doi.org/10.1016/j.indmarman.2010.08.004

Johannisson, B. (1986). "Network Strategies: Management Technology For Entrepreneurship And Change". International Small Business Journal, 5(1), 283-299. https://doi.org/10.1177/07399863870092005

Johanson, J. ve Mattsson, L. G. (1988). Internationalisation In Industrial Systems - A Network Approach. Içinde 
Hood and Vahlne (eds): (Ed.), Strategies in Global Competition (ss. 287-314). London: Croom Helm. https://doi.org/10.1057/9781137508829.0011

Johanson, J. ve Vahlne, J.-E. (1977). "The Internationaliztion Process Of The Firm-A Model Of Knowledge Development And Increasing Foreign Market Commitments". Journal of International Business Studies, 8(1), 2332. https://doi.org/10.2307/254397

Johanson, J. ve Vahlne, J.-E. (1992). "Management Of Foreign Market Entry". Scandinavian International Business Review, 1(3), 9-27. https://doi.org/10.1016/0962-9262(92)90002-N

Johanson, J. ve Vahlne, J.-E. (2003). "Business Relationships Learning And Commitment In The Internationalization Process". Journal of International Entrepreneurship, 1(1), 83-101. https://doi.org/10.1023/A

Johanson, J. ve Vahlne, J. E. (1990). "The Mechanism Of Intenationalisation". International Marketing Review, 7(4), 11-24.

Johanson, J. ve Vahlne, J. E. (2009). "The Uppsala Internationalization Process Model Revisited: From Liability Of Foreignness To Liability Of Outsidership". Journal of International Business Studies, 40(9), 1411-1431. https://doi.org/10.1057/jibs.2009.24

Johanson, J. ve Wiedersheim-Paul, F. (1975). "The Internationalization Of the Firm -Four Swedish Cases". Journal of Management Studies, 12(3), 305-322.

Karra, N. ve Philips, N. (2004). "Entrepreneurship Goes Global Think". Ivey Business Jornal, 67(2), 1-7. https://doi.org/10.1016/j.pneumo.2010.03.002

Knight, G. A. ve Cavusgil, S. T. (2004). "Innovation, Organizational Capabilities, And The Born-Global Firm". Journal of International Business Studies, 35(2), 124-141.

Knight, G. A. ve Çavuşgil, T. (1996). "The Born Global Firm: A Challenge To Traditional Internationalization Theory". Advances in International Marketing, 8, 11-26.

Knight, G. A., Madsen, T. K. ve Servais, P. (2004). "An Inquiry Into Born-Global Firms In Europe And The USA". International Marketing Review, 21(6), 645-665.

Komulainen, H., Mainela, T. ve Tähtinen, J. (2006). "Social Networks In The Initiation Of The High Tech Firm' s Internationalisation". International Journal of Entrepreneurship and Innovation Management, 6(6), 526-541.

KOSGEB Kobi ve Girişimcilik Ödülleri Uygulama Esasları. www.kosgeb.gov.tr (30.04.2018)

Kontinen, T. ve Ojala, A. (2011). "Network Ties In The International Opportunity Recognition Of Family Smes". International Business Review, 20(4), 440-453. https://doi.org/10.1016/j.ibusrev.2010.08.002

Madsen, T. K., Rasmussen, E. ve Servais, P. (2000). Differences And Similarities Between Born Globals And Other Types Of Exporters. Globalization, the Multinational Firm,and Emerging Economies, 10, $247-265$. 
Madsen, T. K. ve Servais, P. (1997). "The Internationalization Of Born Globals: An Evolutionary Process?" International Business Review, 6(6), 561-583. https://doi.org/10.1016/S0969-5931(97)00032-2

Manolova, T. S., Manev, I. M. ve Gyoshev, B. S. (2010). "In Good Company: The Role Of Personal And InterFirm Networks For New-Venture Internationalization In A Transition Economy". Journal of World Business, 45(3), 257-265. https://doi.org/10.1016/j.jwb.2009.09.004

Masango, S. ve Marinova, S. (2014). "Knowledge-Based Network Ties In Early Rapidly İnternationalising Small Firms: A Missing Link?" International Entrepreneurship and Management Journal, 10(3), 471-486. https://doi.org/10.1007/s11365-014-0311-x

McAuley, A. (1999). "Entrepreneurial Instant Exporters In The Scottish Arts And Crafts Sector". Journal of International Marketing, 7(4), 67-82. https://doi.org/10.2307/25048786

McDougall, P. P., Shane, S. ve Oviatt, B. M. (1994). "Explaining The Formation Of International New Ventures: The Limits Of Theories From International Business Research". Journal of Business Venturing, 9(6), 469-487. https://doi.org/10.1016/0883-9026(94)90017-5

Melen, S. ve Nordman, E. R. (2007). "The Value Of Human Capital For The Networks Of Born Globals". International Journal of Globalisation and Small Business, 2(2), $205-219$. https://doi.org/10.1504/IJGSB.2007.015482

Melin, L. (1987). "The Field-Of-Force Metaphor: A Study In Industrial Change". International Studies of Management \& Organization, 17(1), 24-33.

Moen, Ø. (2002). "The Born Globals - A New Generation Of Small European Exporters". International Marketing Review, 19(2/3), 156-175. https://doi.org/10.1108/02651330210425015

Moen, Ø. ve Servais, P. (2002). "Born Global Or Gradual Global? Examining The Export Behavior Of Small And Medium-Sized Enterprises". Journal of International Marketing, 10(3), 49-72. https://doi.org/10.1509/jimk.10.3.49.19540

Mort, G. S. ve Weerawardena, J. (2006). "Networking Capability And International Entrepreneurship". International Marketing Review, 23(5), 549-572. https://doi.org/10.1108/02651330610703445

Nummela, N. (2002). Change in SME internationalisation: A Network perspective. 28th EIBA Conference December 8-10, 2002 Athens, Greece. https://doi.org/10.1108/14626000610705750

O’Donnel, A., Gilmore, A., Cummins, D. ve Carson, D. (2001). "The Network Construct In Entrepreneurship Research: A Review And Critique". Management Decision, 39(9), 749-760. https://doi.org/10.1108/EUM0000000006220

Oviatt, B. M. ve McDougall, P. P. (2005). "Toward A Theory Of International New Ventures". Journal of International Business Studies, 36(1), 29-41. https://doi.org/10.1057/palgrave.jibs.8400128 
Oviatt, B. ve McDougall, P. (1994). "Toward A Theory Of International New Ventures". Journal of International Business Studies, 25(1), 45-64. https://doi.org/10.1057/palgrave.jibs.8490193

Özgen, E. ve Baron, R. A. (2007). "Social Sources Of Information In Opportunity Recognition : Effects Of Mentors, Industry Networks, And Professional Forums". Journal of Business Venturing, 22, 174-192. https://doi.org/10.1016/j.jbusvent.2005.12.001

Patton, M. Q. (1990). Qualitative Evaluation and Research Methods). Sage Publications (Second Edition).

Prashantham, S. ve Dhanaraj, C. (2010). "The Dynamic Influence Of Social Capital On The International Growth Of New Ventures". Journal of Management Studies, 47(6), 967-994. https://doi.org/10.1111/j.14676486.2009.00904.x

Rasmussan, E. S., Koed Madsen, T. ve Evangelista, F. (2001). "The Founding Of The Born Global Company In Denmark And Australia: Sensemaking And Networking". Asia Pacific Journal of Marketing and Logistics, 13(3), 75-107. https://doi.org/10.1108/13555850110764793

Reid, S. D. (1981). "The Decision-Maker And Export Entry And Expansion". Journal of International Business Studies, 12(2), 101-112.

Rennie, M. W. (1993). "Global Competitiveness: Born Global". McKinsey Quarterly, (4), 45-52.

Rialp, A., Rialp, J. ve Knight, G. A. (2005). "The Phenomenon Of Early Internationalizing Firms: What Do We Know After A Decade (1993-2003) Of Scientific Inquiry?" International Business Review, 14(2), 147-166. https://doi.org/10.1016/j.ibusrev.2004.04.006

Riddle, L. A. ve Gillespie, K. (2003). "Information Sources For New Ventures In The Turkish Clothing Export Industry". Small Business Economics, 20(1), 105-120. https://doi.org/10.1023/A:1020252606058

Sapienza, H. J., Autio, E., George, G. ve Zahra, S. A. (2006). "A Capabilities Perspective On The Effects Of Early Internationalization On Firm Survival And Growth". Academy of Management Review, 31(4), 914-933. https://doi.org/10.5465/AMR.2006.22527465

Seggie, F. N. ve Bayyurt, Y. (Ed.). (2015). Nitel Araştırma: Yöntem, Teknik, Analiz ve Yaklaşımları (1. Baskı). Ankara: Anı Yayıncilık.

Sharma, D. D. ve Blomstermo, A. (2003). "The Internationalization Process Of Born Globals: A Network View". International Business Review, 12(6), 739-753. https://doi.org/10.1016/j.ibusrev.2003.05.002

Sharma, D. D. ve Johanson, J. (1987). "Technical Consultancy In Internationalisation". International Marketing Review, 4(4), 20-29.

Slotte-Kock, S. ve Coviello, N. (2010). "Entrepreneurship Research On Network Processes: A Review And Ways Forward". Entrepreneurship: Theory And Practice, 34(1), 31-57. https://doi.org/10.1111/j.15406520.2009.00311.x 
Strauss, A. L. ve Corbin, J. M. (1990). Basics Of Qualitative Research: Grounded Theory Procedures And Techniques. Sage Publications.

Strauss, A. L. ve Corbin, J. M. (1998). Basics Of Qualitative Research: Grounded Theory Procedures And Techniques.. Sage Publications (Second Edition). https://doi.org/10.2307/328955

Tang, Y. K. (2011). "The Influence Of Networking On The Internationalization Of Smes: Evidence From Internationalized Chinese Firms". International Small Business Journal, 29(4), 374-398. https://doi.org/10.1177/0266242610369748

Vasilchenko, E. ve Morrish, S. (2011). "The Role Of Entrepreneurial Networks In The Exploration and Exploitation of Internationalization Opportunities by Information and Communication Technology Firms". Journal of International Marketing, 19(4), 88-105. https://doi.org/10.1509/jim.10.0134

Yin, R. K. (1994). Case Study Research: Design and Methods. Sage Publications (Second Edition). https://doi.org/10.1016/j.jada.2010.09.005

Yin, R. K. (2003). Case Study Research: Design and Methods. Sage Publications (Third Edition).

Yin, R. K. (2014). Case Study Research: Design and Methods Sage Publications (Fifth Edition).

Yıldırım, A. ve Şimşek, H. (2016). Sosyal Bilimlerde Nitel Araştırma Yöntemleri (10. Baskı). Ankara: Seçkin Yayıncilik.

Zain, M. ve Ng, S. I. (2006). "The Impacts Of Network Relationships On SMEs' Internationalization Process". Thunderbird International Business Review, 48(2), 183-205. https://doi.org/10.1002/tie

Zhou, L., Wu, W. P. ve Luo, X. (2007). "Internationalization And The Performance Of Born-Global SMEs: The Mediating Role Of Social Networks". Journal of International Business Studies, 38(4), 673-690. https://doi.org/10.1057/palgrave.jibs.8400282 